July 2002 • NREL/TP-510-32424

\title{
Summary of Chariton Valley Switchgrass Co-Fire Testing at the Ottumwa Generating Station in Chillicothe, lowa
}

\section{Milestone Completion Report}

\author{
W. Amos
}

Prepared for the U.S. Department of Energy's Biomass Power Program and the Chariton Valley Biomass Project

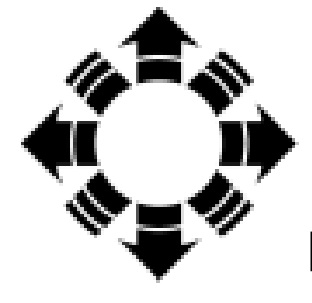

\section{NPEI}

National Renewable Energy Laboratory

1617 Cole Boulevard

Golden, Colorado 80401-3393

NREL is a U.S. Department of Energy Laboratory

Operated by Midwest Research Institute • Battelle • Bechtel

Contract No. DE-AC36-99-G010337 
July 2002 • NREL/TP-510-32424

\section{Summary of Chariton Valley Switchgrass Co-Fire Testing at the Ottumwa Generating Station in Chillicothe, lowa}

\section{Milestone Completion Report}

\section{W. Amos}

Prepared for the U.S. Department of Energy's Biomass Power Program and the Chariton Valley Biomass Project

Prepared under Task No. BP01.1026

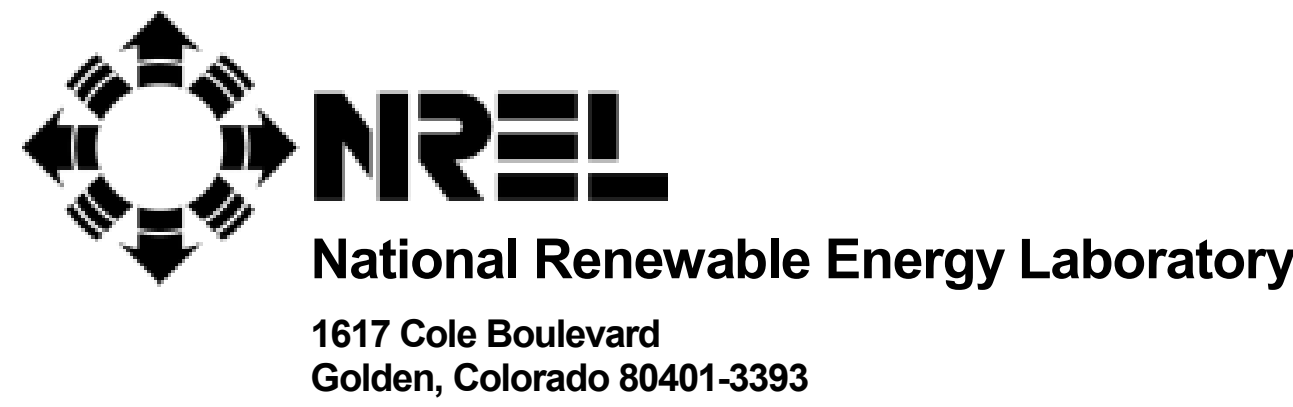

NREL is a U.S. Department of Energy Laboratory Operated by Midwest Research Institute $\bullet$ Battelle $\bullet$ Bechtel

Contract No. DE-AC36-99-G010337 


\section{NOTICE}

This report was prepared as an account of work sponsored by an agency of the United States government. Neither the United States government nor any agency thereof, nor any of their employees, makes any warranty, express or implied, or assumes any legal liability or responsibility for the accuracy, completeness, or usefulness of any information, apparatus, product, or process disclosed, or represents that its use would not infringe privately owned rights. Reference herein to any specific commercial product, process, or service by trade name, trademark, manufacturer, or otherwise does not necessarily constitute or imply its endorsement, recommendation, or favoring by the United States government or any agency thereof. The views and opinions of authors expressed herein do not necessarily state or reflect those of the United States government or any agency thereof.

Available electronically at http://www.osti.gov/bridge

Available for a processing fee to U.S. Department of Energy

and its contractors, in paper, from:

U.S. Department of Energy

Office of Scientific and Technical Information

P.O. Box 62

Oak Ridge, TN 37831-0062

phone: 865.576.8401

fax: 865.576.5728

email: reports@adonis.osti.gov

Available for sale to the public, in paper, from:

U.S. Department of Commerce

National Technical Information Service

5285 Port Royal Road

Springfield, VA 22161

phone: 800.553.6847

fax: 703.605.6900

email: orders@ntis.fedworld.gov

online ordering: http://www.ntis.gov/ordering.htm 


\section{EXECUTIVE SUMMARY}

After several years of planning, the Chariton Valley Biomass Project successfully completed two months of switchgrass co-fire testing at the Ottumwa Generating Station (OGS) in Chillicothe, Iowa. From November 30, 2000, through January 25, 2001, the switchgrass team co-fired 1,269 tons $(1,151$ tonnes) of switchgrass at rates up to 16.8 tons/h $(15.2$ tonne/h), representing about $3 \%$ heat input to the $725-\mathrm{MW}$ power plant. Stack testing was completed when co-firing switchgrass and when burning only coal. Fuel and ash samples were collected for analysis, and boiler performance and emissions data were collected. Numerous improvements were made to the feed-handling equipment during testing. The co-fire testing was completed with no environmental incidents, no injuries to personnel, and no loss in electricity output from OGS.

The goals of the this - the first of three rounds of co-fire tests-were: to identify the effects of co-firing on boiler performance, to measure any changes in emissions during co-firing, and to gather information to improve the design of the switchgrass handling equipment. All three of these goals were met. The design target for the switchgrass handling system was $12.5 \mathrm{ton} / \mathrm{h}$ (11.3 tonne/h), which we exceeded after a redesign of the secondary grinder in our system. We had hoped to burn over 3,000 tons (2,722 tonnes) of switchgrass during this first round of testing, but because of poor equipment performance in December, we were unable to meet this target before the planned boiler shutdown in January. There were, however, several days in January when we burned more than 100 tons (91 tonnes) of switchgrass.

Several important lessons were learned about the feed-handling system. Dust control had been a concern from the start, but after modifying the equipment to maintain a slight negative pressure downstream of the grinding equipment, there were no problems. We also experimented with a piece of equipment called the Eliminator for grinding the switchgrass. Unlike a hammer mill, it used attrition as the primary means of size reduction. The particle size leaving the unit was determined by the residence time and the amount of material flowing through the unit. The Eliminator produced an acceptable particle size with relatively low power consumption, but did not reduce the size of the switchgrass nodes and initially, it required some modifications to get the correct residence time in the unit.

The results of the fuel and ash analyses held no surprises. The switchgrass, when compared to the coal, had higher chlorine and potassium concentrations, but lower sulfur and sodium levels. Because the Powder River Basin coal burned at OGS is relatively high in moisture, there wasn't a large difference in heating value between the coal and the switchgrass.

Analysis of the boiler emissions was problematic. During our co-fire stack testing, a problem unrelated to the switchgrass testing caused high carbon monoxide levels in the flue gas, but further flue gas sampling showed that carbon monoxide emissions were not significantly affected by co-firing. The sulfur emissions, based on continuous emissions monitoring data, decreased during co-firing due to the lower sulfur content of the switchgrass. Nitrogen oxide levels were higher on average, but upsets in the feed-handling system and differences in boiler load may have contributed to the higher nitrogen oxide emissions. 
Bulk switchgrass densities were measured at various points in the system; these data will help with the redesign of the feed-handling system for continuous operation. The system used for the first round of co-fire testing required four operators and was normally run for just one shift per day. The second round of switchgrass testing will evaluate the performance of a system designed to run continuously with minimal operator attention.

After the project team demonstrates that switchgrass can be burned on a continuous basis and that the feed-handling system can provide a stable flow of switchgrass to OGS boiler, we will begin longer-term boiler studies to evaluate corrosion and fouling effects of co-firing switchgrass. 


\section{TABLE OF CONTENTS}

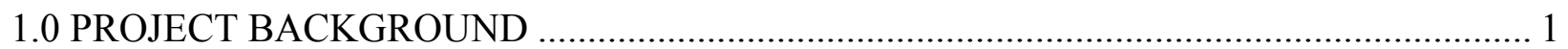

1.1 Scope

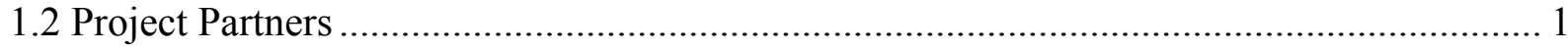

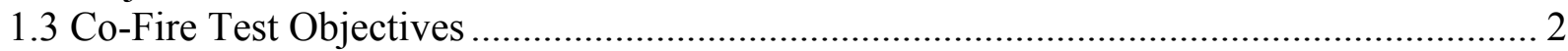

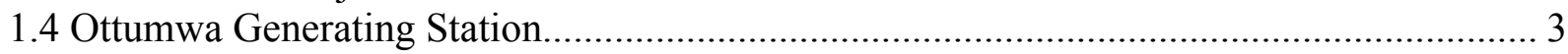

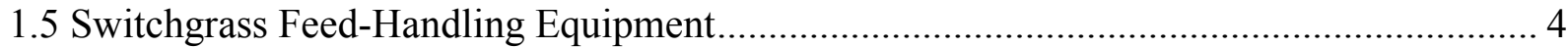

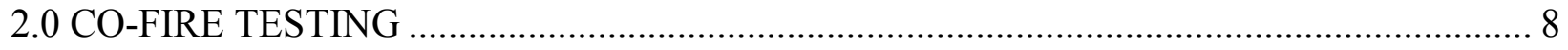

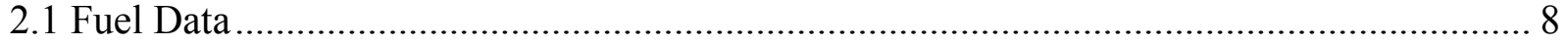

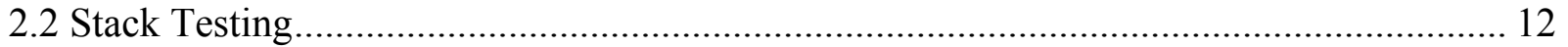

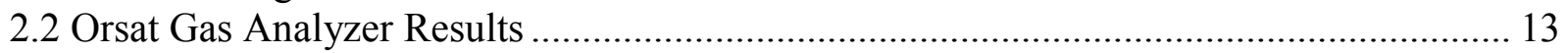

2.3 Continuous Emissions Monitoring Results.................................................................... 14

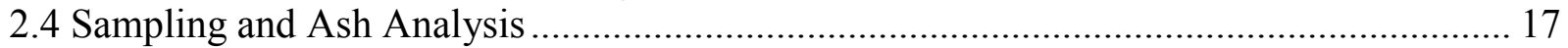

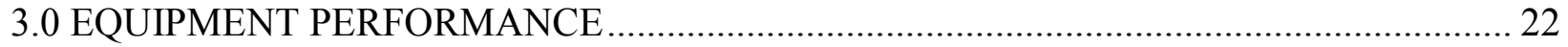

3.1 Equipment Modifications \& Repairs ........................................................................ 22

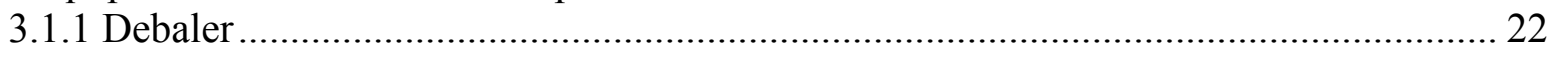

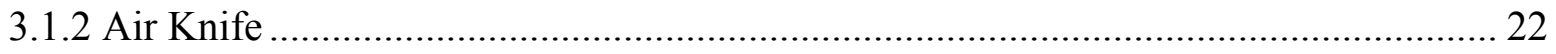

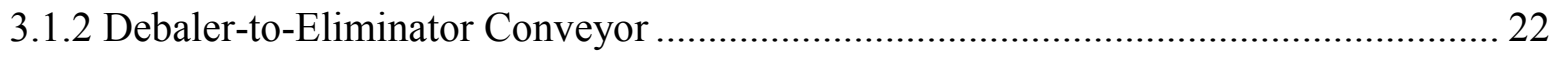

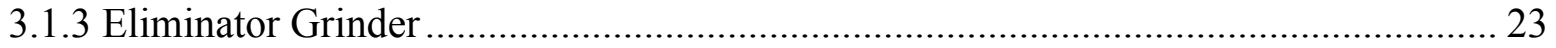

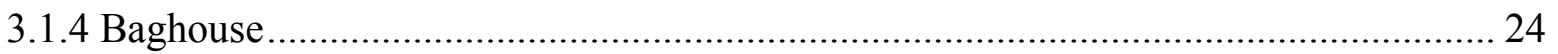

3.1.5 Baghouse Conveyor ........................................................................................... 24

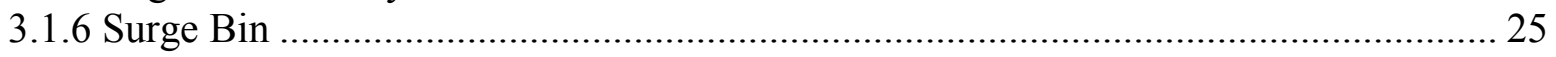

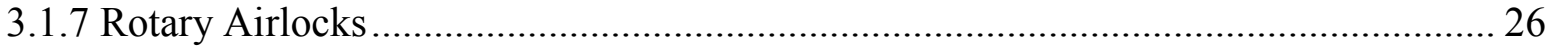

3.1.8 Pneumatic Transport Blowers \& Transport Piping...................................................... 26

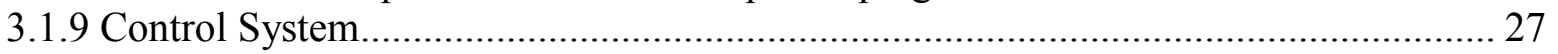

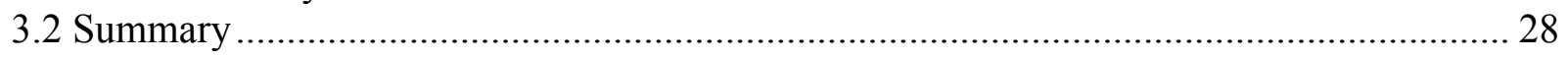

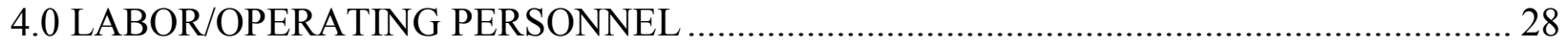

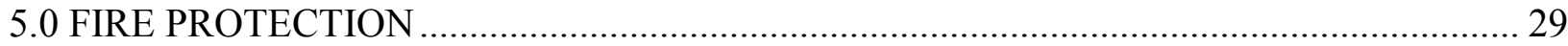

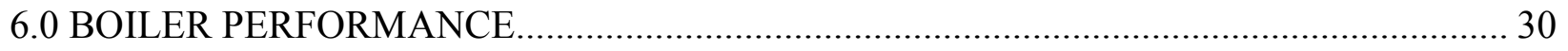

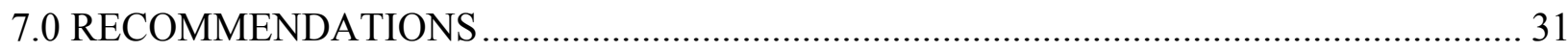




\section{FIGURES}

Figure 1.1 - Flowsheet of the Switchgrass Feed-Handling System ....................................... 4

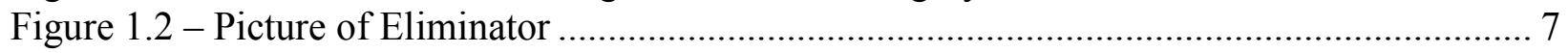

Figure 1.3- Diagram of Eliminator Discharge Chute ....................................................... 7

Figure 2.1 - Comparison of $\mathrm{SO}_{2}$ Emissions when Co-Firing ................................................ 15

Figure 2.2 - Comparison of $\mathrm{NO}_{\mathrm{x}}$ Emissions when Co-Firing ............................................ 16

Figure 2.3 - Comparison of Opacity when Co-Firing ......................................................... 16

\section{TABLES}

Table 2.1 - Daily Switchgrass Totals ............................................................................. 9

Table 2.2 - Composition and Fuel Value of Coal and Switchgrass ......................................... 10

Table 2.3 - Ash \& Trace Element Analyses of Coal and Switchgrass ..................................... 11

Table 2.4 - Switchgrass Size Distribution ......................................................................... 12

Table 2.5 - Bulk Switchgrass Densities ........................................................................... 12

Table 2.6 - Base-line and Co-fire Stack Test Results ............................................................ 13

Table 2.7 - Orsat Gas Analyzer Results (ppm) ................................................................... 13

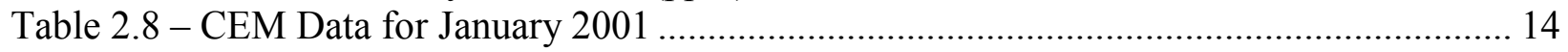

Table 2.9 - Fly Ash Data for Baseline Coal-Only Conditions .............................................. 18

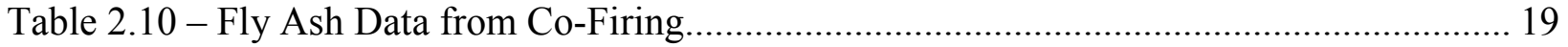

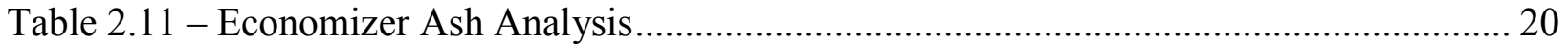

Table 2.12 - Bottom Ash Analysis .................................................................................... 21

Table 2.13 - Analysis of Bottom Ash Water....................................................................... 21 


\subsection{PROJECT BACKGROUND}

\subsection{Scope}

This report summarizes the results of the first switchgrass (Panicum vigatum) co-fire test campaign at the Ottumwa Generating Station (OGS), conducted as a part of the Chariton Valley Biomass Project (U.S. DOE Contract DE-FC36-96GO10148). This report focuses primarily on the co-fire testing conducted at OGS, which is only a part of the larger Chariton Valley Biomass Project. The larger project addresses the agronomic, environmental, and economic aspects of switchgrass production, in addition to the technical questions answered by the co-fire testing at OGS.

\subsection{Project Partners}

The efforts of a number of people were responsible for the successful demonstration of switchgrass co-firing at the Ottumwa Generation Station. The following is a partial list of those directly involved with the first round of testing and their roles.

Chariton Valley RC\&D, Inc., Centerville, Iowa - Chariton Valley RC\&D was the project sponsor and provided overall project coordination for the Chariton Valley Biomass Project, including the co-fire portion of the project

Alliant Energy, Cedar Rapids, Iowa - Alliant Energy was a principal project partner in the Chariton Valley Biomass Project and hosted the first round of co-fire testing at its 725-MW boiler in Chillicothe, Iowa.

U.S. Department of Energy (DOE), Washington, D.C., and Golden, Colorado - The U.S. DOE provided funding for the Chariton Valley Biomass Project and co-fire testing. The Golden Field Office managed the cooperative agreement for the DOE.

Ottumwa Generating Station, Chillicothe, Iowa - OGS hosted the first round of switchgrass cofire testing and provided operating staff for project meetings, sample collection, and stack gas testing.

National Renewable Energy Laboratory (NREL), Golden, Colorado - NREL provided on-site startup support and test coordination, in addition to developing the sampling plan for the testing.

Sandia National Laboratories, Livermore, California \& Albuquerque, New Mexico - Sandia provided the data acquisition system for collecting boiler performance data, developed the test plan for the first round of co-fire testing, and assisted with startup support during co-fire testing.

Kelderman Manufacturing, Inc., Oskaloosa, Iowa - Kelderman Manufacturing provided operating staff for the switchgrass co-fire testing and was responsible for final installation and modifications to the switchgrass handling system during testing. 
Tech-wise A/S, Fredericia, Denmark - Tech-wise provided engineering and startup support for the first round of co-fire testing. Tech-wise has supervised several wheat straw co-firing tests in Denmark.

T. R. Miles Technical Consultants, Inc. - T. R. Miles provided technical assistance, startup support, and design review services for the Chariton Valley switchgrass co-fire testing.

Delta Process Technologies/Dolthan Group, LLC, Mobile, Alabama - Delta Process Technologies provided the Eliminator grinder that was used for switchgrass processing at OGS, and provided startup and sampling support during testing.

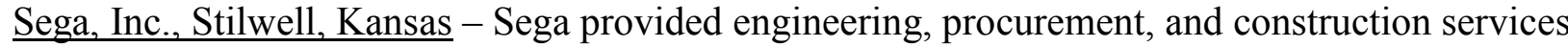
for the switchgrass handling facility at OGS.

Foster Wheeler Development Corporation, Clinton, New Jersey - Foster Wheeler developed the preliminary design of the feed handling system used for co-fire testing and installed the switchgrass nozzle inserts for the OGS boiler.

R. W. Beck, Madison, Wisconsin - R.W. Beck conducted the initial feasibility studies on the possibility of co-firing switchgrass in the OGS boiler.

Prairie Lands Bio-Products, Inc., Lucas, Wayne, Monroe, and Appanoose Counties, Iowa Prairie Lands is a farmer cooperative that provided much of the switchgrass used during testing. Many of the operating personnel running the switchgrass handling facility were Prairie Lands members.

MidAmerican Energy Company, Des Moines, Iowa - MidAmerican Energy is a co-owner of Ottumwa Generation Station.

Iowa Department of Natural Resources (DNR), Des Moines, Iowa - The Iowa DNR worked with the Chariton Valley Biomass Project and the U.S. Environmental Protection Agency in granting variances for co-fire testing at OGS.

Oak Ridge National Laboratory (ORNL), Oak Ridge, Tennessee - ORNL provided technical and financial support for agronomic and environmental research supporting the switchgrass production for the project.

\subsection{Co-Fire Test Objectives}

This report summarizes the results of the first of three proposed co-fire test campaigns planned at the Ottumwa Generating Station. There were three chief goals of the first co-fire test campaign. First, it was important to see if there were any adverse effects on the boiler operation due to the co-firing of switchgrass. Possible problems might include increased slagging and/or fouling of heat transfer surfaces, conflicts with fuel and oxygen controls, increased corrosion of heat transfer surfaces, or decreased boiler efficiency. The second purpose of the testing was to investigate the effects of co-firing on boiler emissions. Because of differences in chemical 
composition, one concern was the effect of the switchgrass on the electrostatic precipitator (ESP) performance. It was also important to verify the expected decrease in sulfur dioxide emissions and determine whether co-firing might reduce nitrogen oxide emissions. The third purpose of the co-firing was to learn more about the material handling properties of the switchgrass for the proper design of feed-handling systems. Particle-size reduction, the option of using round bales, and dust control in the switchgrass building were at the top of the list of questions to be answered.

The second and third planned co-fire test campaigns will address improvements in the feedhandling system and long-term boiler effects. The system used for the first co-fire test campaign worked effectively for the purposes stated above, but did not represent a commercial system. A minimum of three people was required for system operation with additional personnel required for rest breaks and unloading trucks. The system was also only operated one or two shifts per day. In the second co-fire test campaign, improvements will be made to allow continuous, unattended operation of the switchgrass handling system. This will require an automated balehandling system, upgraded controls, and equipment reliability improvements. The second co-fire test campaign will use the current system size of 12.5 tons/h $(11.3$ tonne/h) and could burn up to 6,000 tons $(5,443$ tonnes $)$ of switchgrass. The third co-fire campaign will look at long-term boiler effects with the goal of co-firing switchgrass for some 2,000 hours at the 12.5 tons/h (11.3 tonne/h) feed rate. This testing will answer questions about corrosion and fouling in the boiler. The size of the final commercial system will be 25 tons $/ \mathrm{h}(22.7$ tonne $/ \mathrm{h})$.

\subsection{Ottumwa Generating Station}

Ottumwa Generating Station is a 725-MW gross (675-MW net) tangentially-fired pulverized coal boiler burning low-sulfur Wyoming Powder River Basin coal. The plant is one of the largest power plants in Iowa and is located in Chillicothe, Iowa, about ten miles northwest of Ottumwa. The plant began commercial operation in 1981 and is owned jointly by Alliant Energy and MidAmerican Energy.

The plant has two fireballs (east and west) without a dividing wall between the two fireballs. This was one of the first plants built without a dividing wall. Eliminating the dividing wall reduced the capital costs, and eliminated problems associated with soot blowing and keeping the dividing wall clean. The plant has seven coal mills, with each supplying one row of eight burners - four burners on each corner of the two fireballs. Under normal operation, only six of the seven coal mills are in operation and the power plant rotates which coal mill is shutdown. The gases leaving each fireball pass through the reheat and superheater tubes, then pass down through the economizer before making a turn up into the hot-side electrostatic precipitator. Some of the larger ash falls out on the upward turn after the economizer. This material is referred to as "economizer ash" in this report and includes unburned fuel, larger pieces of ash, pieces of slag, and occasional bits of refractory. The economizer ash is periodically emptied to the ash pond through an eduction system. 
The east and west flue gas flows on each side of the boiler are further split upon entering the ESP. The gases pass through six ESP fields, with every two ESP fields emptying into a fly ash hopper. This means that for any path through the ESP, it is possible to get three ash samples: the ash removed in the first two fields, the ash removed in the middle two fields and the ash removed in the last two fields of the ESP. During testing, fly ash samples were collected from all three fly ash hoppers from corresponding rows on both the east and west sides of the boiler. Because of the high ESP efficiency, it sometimes was not possible to collect any ash from the final, outlet ash hopper. The fly ash from each hopper is pneumatically conveyed to a large ash storage bin, where it is loaded into trailer trucks and normally sold as Class C fly ash for concrete manufacture. Ash derived from non-coal sources cannot be used for concrete manufacture, per ASTM standards, so during co-fire testing, the ash was sold at a loss for other uses. OGS produces an average of 300 tons ( 272 tonnes) of fly ash per day.

After leaving the ESP, the flue gas passes through a pair of basket air-heaters, which preheat the primary and secondary combustion air. The flue gases are pulled through the four parallel induced-draft (ID) fans and exit through the 600-ft. (183-m) stack. OGS has continuous emissions monitors for $\mathrm{SO}_{2}, \mathrm{NO}_{\mathrm{x}}$, and opacity. During the winter months, primary combustion air is preheated using steam from the de-aerator.

The steam cycle of the power plant operates at a maximum drum pressure of 2,990 psig (20.6 $\mathrm{MPa})$ and with a superheat temperature of $1,005^{\circ} \mathrm{F}\left(541^{\circ} \mathrm{C}\right)$. The steam passes through the highpressure turbine and the flow is split and returned to the boiler to be reheated at a maximum of $680 \mathrm{psi}(5.9 \mathrm{MPa})$ and $1,005^{\circ} \mathrm{F}\left(541^{\circ} \mathrm{C}\right)$. The two separate reheat streams pass through the lowpressure bottoming turbines and the exhaust is condensed using $140,000 \mathrm{gpm}\left(8.8 \mathrm{~m}^{3} / \mathrm{s}\right)$ of water from the plant's two cooling towers. The condensate is heated in low-pressure and high-pressure heaters using extraction steam, before passing through the economizer and returning to the steam drum. The maximum rated capacity is $4,850,000 \mathrm{lb} / \mathrm{h}(2,200$ tonne/h) of steam with a reheat flow of 4,440,000 lb/h (2,000 tonne/h).

\subsection{Switchgrass Feed-Handling Equipment}

Figure 1.1 shows a layout of the switchgrass feed-handling equipment. Several modifications were made to the switchgrass feed-handling equipment during testing. What follows is a description of the final system design. Details on these modifications are discussed in Section 3 of the report.

\section{Figure 1.1 - Flowsheet of the Switchgrass Feed-Handling System}

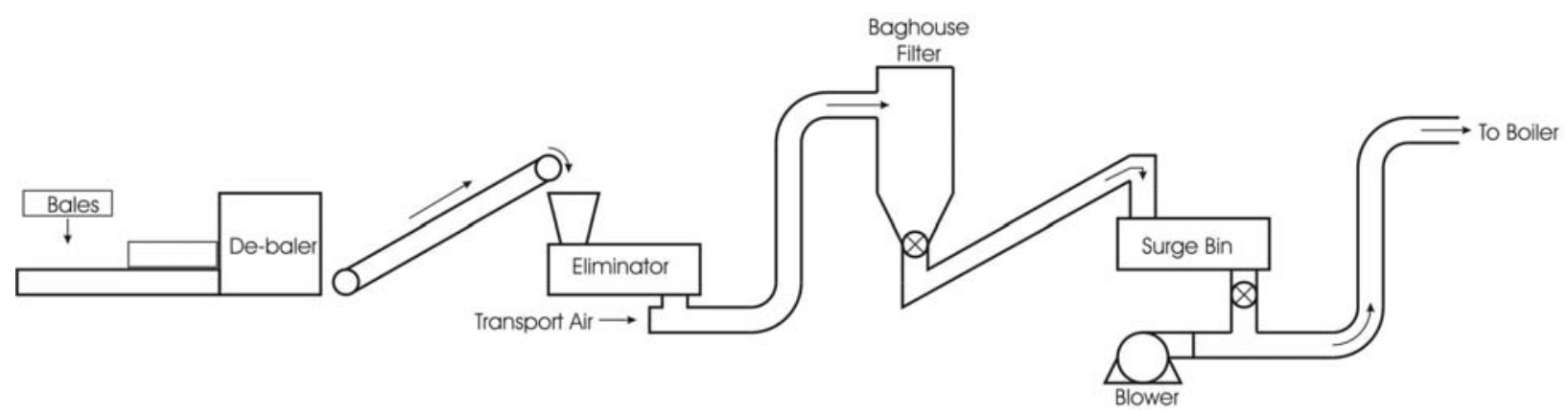


A 12,000 sq. ft. $\left(1,100 \mathrm{~m}^{2}\right)$ building was constructed behind OGS to house both the feed handling equipment and to store approximately 300 tons ( 272 tonnes) of switchgrass. The original hope was to use $3 \mathrm{ft} \times 3 \mathrm{ft} \times 8 \mathrm{ft}(0.9 \mathrm{~m} \times 0.9 \mathrm{~m} \times 2.4 \mathrm{~m})$ or " $3 \times 3$ " bales, $3 \mathrm{ft} \times 4 \mathrm{ft} \times 8 \mathrm{ft}$ $(0.9 \mathrm{~m} \times 1.2 \mathrm{~m} \mathrm{x} 2.4 \mathrm{~m})$ or " $3 \times 4$ " bales, and $6 \mathrm{ft}(1.8 \mathrm{~m})$ round bales during switchgrass testing. However, we quickly found that the round bales, because of the variation in density between the outside layers and the core, could not be fed evenly into our equipment. For that reason, testing was restricted to the $3 \times 3$ and $3 \times 4$ bales, which weighed $700 \mathrm{lbs}(318 \mathrm{~kg})$ and 1,000 $\mathrm{lbs}(454 \mathrm{~kg})$, respectively.

Bales were delivered to OGS by flatbed trailer, with $54-3 \times 3$ or $36-3 \times 4$ bales per truck. The bales were normally unloaded at night or in the early morning so that the fork truck driver was not required to both unload bales from the truck and maintain the feed handling system. The bales could be stacked 6 high ( $18 \mathrm{ft}$ or $5.5 \mathrm{~m}$ ) in the storage area and three $3 \times 3$ or three $3 \times 4$ bales could be handled at a time, using a telescoping fork truck with a special bale pusher mounted on the fork.

The bales were placed onto a platform with a drag-chain conveyor feeding a Newhouse Big Bale Chopper C5000 "debaler." The debaler platform was $10 \mathrm{ft}(3 \mathrm{~m})$ wide and approximately $20 \mathrm{ft}$ $(6.1 \mathrm{~m})$ long. The bales were placed onto the platform with three $3 \times 3$ bales side-by-side or with two $3 \times 4$ bales side-by-side. After being placed on the platform, the twine was cut with an axe and manually pulled off the bale from the top. The twine had a tendency to wrap around the rotating parts in the feed-handling system or lodge in the baghouse, so it was removed whenever possible.

The bales were pulled into the debaler where a rotating drum mounted with teeth tore the switchgrass straw off the end of the bale one layer at a time. The switchgrass was then pushed out of the side of the debaler with a high-speed screw conveyor. The debaler was powered by a power take-off (PTO) of a tractor and required approximately $85 \mathrm{hp}(63 \mathrm{~kW})$. A variable-speed hydraulic drive controlled the speed of the drag-chain conveyor on the debaler. Because the entire feed-handling system was operated in a starve-fed mode, the drag-chain conveyor speed was the primary method for controlling the switchgrass flow to the boiler.

The switchgrass exiting the debaler was discharged onto an air knife, designed to allow heavy material to drop out through the flow of air, while the lighter switchgrass was blown onto a belt conveyor leading to the Eliminator grinder. The air knife opening was about $3 \mathrm{ft}(1 \mathrm{~m})$ wide and the blower was connected to a variable speed drive that could be adjusted for optimum separation. The air knife blower was designed for entrained solids flow, so it did double duty, controlling dust by pulling a suction on a hood over the air knife and debaler discharge. Any reject material from the air knife was manually removed.

A smooth belt conveyor took the material from the debaler to the inlet chute of the Dothan, Inc. Eliminator grinder. The Eliminator is best described as an attrition mill. It consists of two intermeshing rotating shafts running at $1,300 \mathrm{rpm}$, which throw the material around inside the unit, breaking it up. Figure 1.2 shows a picture of the Eliminator with the top removed. Unlike a hammer mill, the Eliminator has no outlet screen for classifying the material size - the extent of grinding was entirely dependant on the residence time and the amount of material passing 
through the unit. As the residence time increased or the amount of material passing through the unit increased, the particle size decreased. One benefit of the Eliminator design was that as the amount of material passing through the unit increased, the particle size decreased, with no blinding of any outlet screen to limit throughput. The Eliminator was driven by a pair of 300-hp (224-kW) electric motors.

At the outlet of the Eliminator, a 26-in. (0.7-m) duct from the baghouse pulled a partial vacuum on the Eliminator. The Eliminator was originally designed for granular material, and pulling a suction on it was required to help move the lighter switchgrass through the unit. Additional transport air was admitted to the duct through an adjustable slide gate located under the Eliminator. See Figure 1.3 for the details of this equipment arrangement. Under normal operating conditions, the suction at the Eliminator discharge was approximately 8-10 in. of water. The suction at the inlet chute of the Eliminator was approximately 2-4 in. of water.

The air flow from the Eliminator was combined with the flow from several other smaller dust collection lines before entering a Camfil Farr "Big Round Filter" model 231BRF10 baghouse filter. The baghouse contained $231-10 \mathrm{ft}(3 \mathrm{~m}) 16 \mathrm{oz}$. polyester bags, $6 \mathrm{in}$. $(15 \mathrm{~cm})$ in diameter. The airflow entered the baghouse tangentially, like in a cyclone, so the larger pieces of switchgrass dropped to the bottom of the baghouse without contacting the bags, while the bags captured the smaller dust particles. The dust cake forming on the bags was continuously removed using a pulsed air jet from the clean side of the baghouse. The baghouse and dust collection system was rated for $20,000 \mathrm{cfm}\left(9.4 \mathrm{~m}^{3} / \mathrm{s}\right)$ of flow and used a $60-\mathrm{hp}(45-\mathrm{kW})$ Air Tech Fan Corporation model 300B1SW3CD3609 centrifugal blower.

The material was removed from the baghouse using a 30-in. (0.8-m) diameter by 40-in. (1.0-m) long rotary valve, custom built by Kelderman Manufacturing. This material was dropped onto a totally enclosed tube conveyor, which consisted of a belt lying in a curved trough, driven on the upper end. Like all of the equipment downstream of the Eliminator, this conveyor was kept under a slight negative pressure to minimize dust levels in the switchgrass building. The baghouse was located outside of the switchgrass building because of its height, so the tube conveyor passed back inside through the wall of the switchgrass building.

The baghouse tube conveyor dumped into a 96 in. x 120 in. x 80 in. (2.4 m x $3 \mathrm{~m} \mathrm{x} 2 \mathrm{~m}$ ) surge bin, which had two pair of co-rotating $12-\mathrm{in} .(30-\mathrm{cm})$ diameter $14-\mathrm{ft}(4.2-\mathrm{m})$ long screws in the bottom. Each pair of screws fed a Western Pneumatics, Inc. 20 in. x 25 in. $(0.5 \mathrm{~m} \times 0.6 \mathrm{~m})$ rotary airlock, dumping into a pneumatic transport line operating under a few psi $(10 \mathrm{kPa})$ of pressure. Although originally designed to be a surge bin with variable speed screws in the bottom, in the final system design, this bin was run in starve-fed mode with the screws near their maximum rate.

The pneumatic transport system consisted of twin 550-ft (168-m) long 10-in. (0.25 m) schedule20 carbon steel pipes, each fed by a 100-hp (75-kW) Gardner Denver model GKGBDCA positive displacement rotary lobe blower. After entering the power plant, the pipes went to opposing corners of the east fireball. Foster Wheeler switchgrass nozzles injected the switchgrass between the third and fourth rows of coal burners from the bottom. A slide gate at the boiler nozzle was included for positive shutoff of fuel during boiler trips. 
Figure 1.2 - Picture of Eliminator

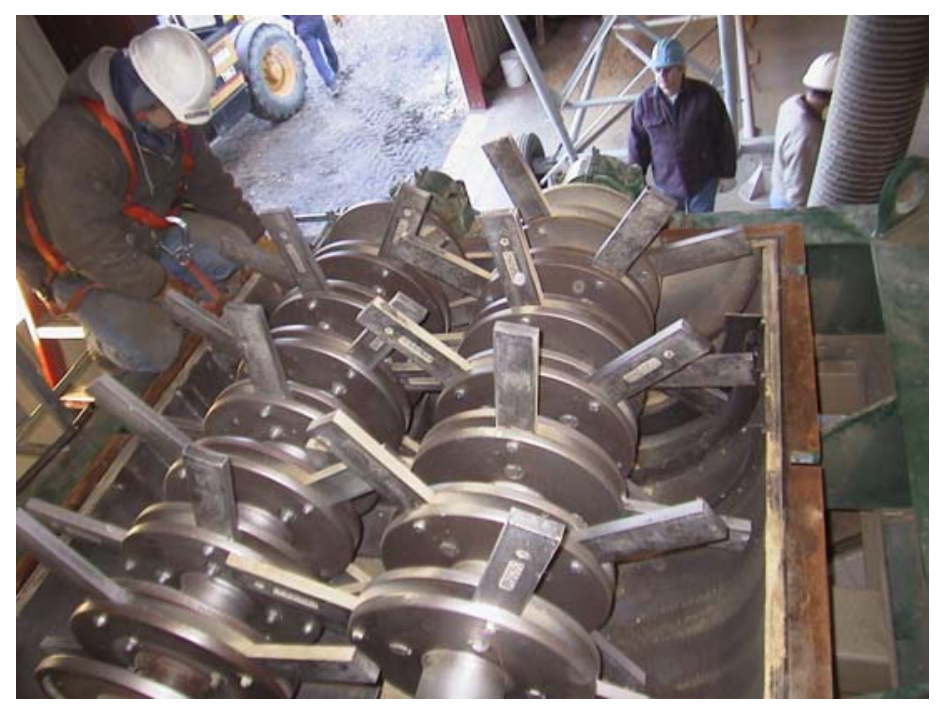

Figure 1.3- Diagram of Eliminator Discharge Chute

Inlet Chute

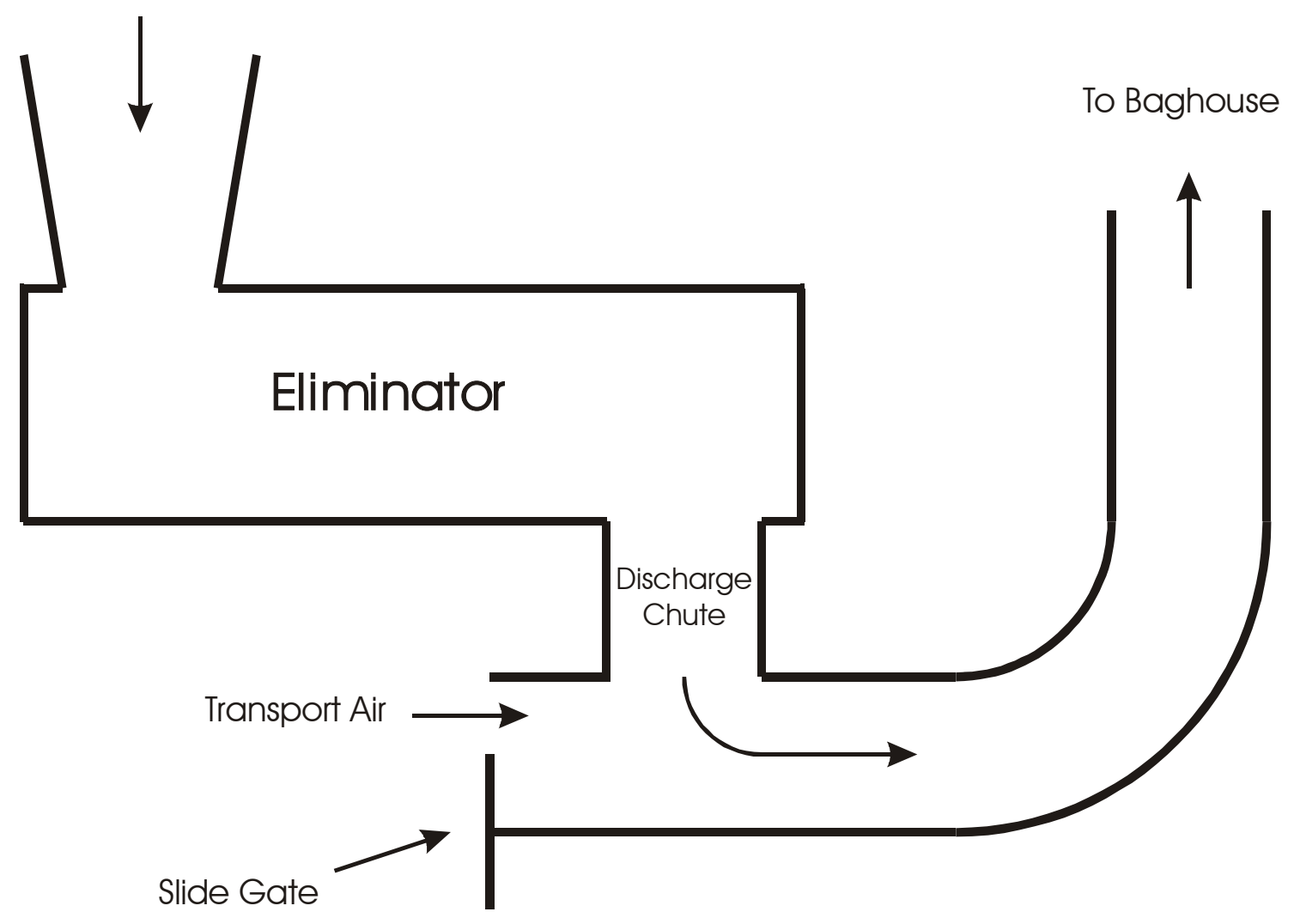


The feed handing system was controlled by an Allen-Bradley SLC 5/3 programmable logic controller with two 16-channel inlet modules and two 16-channel outlet modules. In the OGS control room, there were indicators for the blowers and feed screws, along with a permissive switch and emergency stop for boiler house personnel. In the switchgrass building, there were controls for starting and stopping all the equipment, along with two emergency stop buttons located on opposite sides of the switchgrass equipment room. The speed control for the debaler was a manual hydraulic control, although there was a high-level shutoff tied to ultrasonic level detectors in the surge bin. Under normal operation, the surge bin and baghouse equipment were controlled from the motor control center (MCC), while the conveyors were operated from the control panel in the switchgrass building.

\subsection{CO-FIRE TESTING}

The switchgrass co-fire testing was performed from November 30, 2000, through January 25, 2001. Over this period of time, there were a total of 26 days when some amount of switchgrass was co-fired in the OGS boiler. Normally, no co-firing was done on weekends and there were a number of mechanical- and weather-related delays.

When first started, the system had a very limited throughput of only a few tons per hour. Several minor modifications were made, but the feed rate to the Eliminator grinder was still limited to about 6 tons $/ \mathrm{h}$ (5.4 tonne/h). At the beginning of January, we made a major modification that allowed us to increase the system capacity to more than $15 \mathrm{tons} / \mathrm{h}(13.6$ tonne $/ \mathrm{h})$. A total of 1,269 tons ( 1,151 tonnes) of switchgrass was burned during the test period, with the highest measured rate being 16.8 tons $/ \mathrm{h}(15.2$ tonne/h). Because of our limited capacity to process switchgrass in December, our goal of burning 3,000 tons (2,722 tonnes) of switchgrass was not met; however, we did exceed the original target rate of 12.5 tons $/ \mathrm{h}(11.3$ tonne $/ \mathrm{h})$. Table 2.1 lists the amounts of switchgrass burned each day along with the approximate co-fire rates, if known.

The maximum daily switchgrass total was 178 tons on January 22,2001 . This included $384-3 \times 3$ bales and 88-3x4 bales. All weights are given on an "as received" basis. Bale moisture levels were consistently below $15 \%$ and were estimated to be about $11 \%$ on average.

\subsection{Fuel Data}

The boiler was designed to burn low-sulfur (0.5\%) Wyoming Powder River Basin (PRB) coal. The composition and fuel value are shown in Table 2.2. It is important to note that the lowsulfur PRB coal has a higher moisture content and a lower heating value than bituminous coal. Also shown in Table 2.2 is the composition and fuel value of the switchgrass. The switchgrass used in the first co-fire test campaign was field-dried to less than 15\% moisture and stored inside, so its fuel value is close to that of the PRB coal on an as-received basis. Samples sent back to NREL for moisture analysis returned values ranging from $9 \%-16 \%$, with an average moisture of $11.2 \%$. Laboratory data from Hazen Research gave lower moistures, but there was a delay of several months in sending these samples for analysis. The ash and trace element analyses for both fuels are shown in Table 2.3. One fraction of the switchgrass - the nodeswas analyzed separately. This data is also shown in Tables 2.2 and 2.3. It is suspected that some 
of the ash in the switchgrass samples was associated with dirt picked up during harvesting and bale handling.

Table 2.1 - Daily Switchgrass Totals

\begin{tabular}{|r|r|r|r|r|}
\hline \multicolumn{1}{|c|}{ Date } & $\begin{array}{c}\text { Switchgrass } \\
\text { Burned } \\
\text { tons) }\end{array}$ & $\begin{array}{c}\text { Switchgrass } \\
\text { Burned } \\
\text { (tonnes) }\end{array}$ & $\begin{array}{c}\text { Rate } \\
\text { (ton/h) }\end{array}$ & $\begin{array}{c}\text { Rate } \\
\text { (tonne/h) }\end{array}$ \\
\hline 30-Nov-00 & 2.1 & 1.9 & $2-3$ & $2-3$ \\
\hline 1-Dec-00 & 4.6 & 4.2 & $6-7$ & $5-6$ \\
\hline 4-Dec-00 & 7.1 & 6.4 & 5.5 & 5 \\
\hline 7-Dec-00 & 10.1 & 9.2 & & \\
\hline 8-Dec-00 & 33.0 & 29.9 & & \\
\hline 13-Dec-00 & 2.1 & 1.9 & & \\
\hline 14-Dec-00 & 17.3 & 15.7 & & \\
\hline 15-Dec-00 & 23.0 & 20.9 & & \\
\hline 18-Dec-00 & 48.5 & 43.9 & & \\
\hline 19-Dec-00 & 39.7 & 36.0 & & \\
\hline 20-Dec-00 & 32.2 & 29.2 & & 5.5 \\
\hline 21-Dec-00 & 55.8 & 50.6 & & \\
\hline 22-Dec-00 & 34.0 & 30.8 & & \\
\hline 5-Jan-01 & 2.1 & 1.9 & & \\
\hline 8-Jan-01 & 11.6 & 10.5 & 15 & 14 \\
\hline 10-Jan-01 & 84.0 & 76.2 & 16.5 & 15 \\
\hline 11-Jan-01 & 83.4 & 75.6 & $13-14$ & $12-13$ \\
\hline 12-Jan-01 & 92.4 & 83.8 & & \\
\hline 15-Jan-01 & 138.4 & 125.5 & 12 & 11 \\
\hline 16-Jan-01 & 28.1 & 25.5 & $6-7$ & $5-6$ \\
\hline 17-Jan-01 & 70.0 & 63.5 & $12-13$ & $11-12$ \\
\hline 19-Jan-01 & 39.0 & 35.4 & & \\
\hline 22-Jan-01 & 178.4 & 161.8 & & \\
\hline 23-Jan-01 & 104.9 & 95.1 & & \\
\hline 24-Jan-01 & 63.6 & 57.7 & & \\
\hline 25-Jan-01 & 64.0 & 58.0 & & \\
\hline & & & & \\
\hline
\end{tabular}


Table 2.2 - Composition and Fuel Value of Coal and Switchgrass

\begin{tabular}{|l|l|r|r|r|}
\hline As Received: & & Coal & Switchgrass & Nodes \\
\hline Moisture & $\%$ & 33.52 & 6.34 & 7.22 \\
\hline Ash & $\%$ & 5.51 & 5.35 & 2.56 \\
\hline Volatile & $\%$ & 28.98 & 73.84 & 75.85 \\
\hline Fixed Carbon & $\%$ & 32.00 & 14.48 & 14.38 \\
\hline S & $\%$ & 0.36 & 0.11 & 0.05 \\
\hline Btu/lb (HHV) & Btu/lb & 7,774 & 7,458 & 7,631 \\
\hline MMF Btu/lb & Btu/lb & 8,268 & 7,915 & 7,847 \\
\hline & & & & \\
\hline Dry Basis: & & & & \\
\hline Ash & $\%$ & 8.24 & 5.70 & 2.75 \\
\hline Volatile & $\%$ & 43.60 & 78.84 & 81.75 \\
\hline Fixed Carbon & $\%$ & 48.16 & 15.46 & 15.50 \\
\hline S & $\%$ & 0.55 & 0.12 & 0.05 \\
\hline Btu/lb (HHV) & Btu/lb & 11,696 & 7,965 & 8,225 \\
\hline MMF Btu/lb & Btu/lb & 12,852 & 8,486 & 8,477 \\
\hline MAF Btu/lb & Btu/lb & 12,747 & 8,445 & 8,457 \\
\hline & & & & \\
\hline Ultimate (Dry Basis): & & & & \\
\hline C & $\%$ & 67.98 & 48.41 & 49.49 \\
\hline H & $\%$ & 4.48 & 5.06 & 5.35 \\
\hline N & $\%$ & 1.16 & 0.56 & 0.37 \\
\hline S & $\%$ & 0.55 & 0.12 & 0.05 \\
\hline Ash & $\%$ & 8.24 & 5.70 & 2.75 \\
\hline O & $\%$ & 17.58 & 40.16 & 42.00 \\
\hline Cl & \%/MM Btu & 0.12 & 0.14 & 0.06 \\
\hline Na2O & lb/MM Btu & 7.06 & 1.01 & 0.57 \\
\hline K2O & Ib/MM Btu & 0.93 & 0.19 & 3.37 \\
\hline & & & 0.30 & 0.13 \\
\hline Alkali & 0.067 & 0.003 & 0.003 \\
\hline Ash & $\%$ & 0.809 & 0.438 \\
\hline SO2 & $\%$ & & \\
\hline & $\%$ & & & \\
\hline
\end{tabular}


Table 2.3 - Ash \& Trace Element Analyses of Coal and Switchgrass

\begin{tabular}{|l|l|r|r|r|}
\hline Ash: & & Coal & Switchgrass & Nodes \\
\hline $\mathrm{SiO} 2$ & $\%$ & 35.34 & 57.52 & 42.00 \\
\hline $\mathrm{Al} 2 \mathrm{O} 3$ & $\%$ & 20.03 & 0.70 & 1.37 \\
\hline $\mathrm{TiO} 2$ & $\%$ & 1.20 & 0.26 & 0.11 \\
\hline $\mathrm{Fe} 2 \mathrm{O} 3$ & $\%$ & 5.45 & 0.40 & 0.83 \\
\hline $\mathrm{CaO}$ & $\%$ & 20.27 & 9.10 & 18.47 \\
\hline $\mathrm{MgO}$ & $\%$ & 3.54 & 4.64 & 3.85 \\
\hline $\mathrm{Na} 2 \mathrm{O}$ & $\%$ & 1.22 & 0.55 & 0.48 \\
\hline $\mathrm{K} 2 \mathrm{O}$ & $\%$ & 0.50 & 13.88 & 17.95 \\
\hline $\mathrm{P} 2 \mathrm{O} 5$ & $\%$ & 1.31 & 6.56 & 7.70 \\
\hline $\mathrm{SO} 3$ & $\%$ & 10.24 & 2.41 & 1.73 \\
\hline $\mathrm{Cl}$ & $\%$ & $<0.01$ & 0.93 & 0.30 \\
\hline $\mathrm{CO} 2$ & $\%$ & 0.18 & 1.68 & 2.59 \\
\hline & & & & \\
\hline Trace Elements: & & & & \\
\hline $\mathrm{As}$ & $\mathrm{mg} / \mathrm{kg}$ & 17.7 & 1.2 & 1.2 \\
\hline $\mathrm{Ba}$ & $\mathrm{mg} / \mathrm{kg}$ & 4,727 & 733 & 992 \\
\hline $\mathrm{Cr}$ & $\mathrm{mg} / \mathrm{kg}$ & 93 & 58 & 70 \\
\hline $\mathrm{Cd}$ & $\mathrm{mg} / \mathrm{kg}$ & $<1$ & $<5$ & $<5$ \\
\hline $\mathrm{Pb}$ & $\mathrm{mg} / \mathrm{kg}$ & 33 & 40 & 47 \\
\hline $\mathrm{Hg}$ & $\mathrm{mg} / \mathrm{kg}$ & $<0.1$ & $<0.1$ & $<0.1$ \\
\hline $\mathrm{Ag}$ & $\mathrm{mg} / \mathrm{kg}$ & 2 & $<10$ & 2 \\
\hline $\mathrm{Se}$ & $\mathrm{mg} / \mathrm{kg}$ & 7 & 4 & $<2$ \\
\hline & & & & \\
\hline
\end{tabular}

One question to be answered by the first round of co-fire testing was how effective the Eliminator would be at producing switchgrass with the size distribution necessary for proper combustion in the OGS boiler. The ground switchgrass has three fractions: a micron-sized dust; a large fraction of thin, flat, and long sections of split switchgrass stalk; and a small fraction of round dense nodes that come from where the sections of stem came together. With the Eliminator, the nodes were not reduced in size. While these nodes did not cause any operational problems and were transported through the feed-handling system, once the nodes entered the OGS boiler, they simply dropped to the bottom of the boiler, due to their larger size and higher density relative to the rest of the switchgrass. They were clearly visible floating around the edges of the ash pond and showed almost no charring.

During testing, we were able to isolate and collect relatively pure samples of nodes from the feed-handling system. We were interested in the composition of these nodes because we knew it was possible to pull them out of the main switchgrass stream using an air classifier, if desired. The analysis of the nodes is included in Tables 2.3 and 2.4. We were somewhat surprised to find that, other than the higher potassium content, the nodes appeared to have favorable fuel characteristics, with low ash and low sulfur content.

The size distribution of the ground switchgrass and the node samples are shown in Table 2.4. It is important to note that even though some of the switchgrass pieces are longer than $1 \mathrm{in}$. (2.5 $\mathrm{cm}$ ) in length, they are typically less than $1 / 16$ in. $(1.5 \mathrm{~mm})$ in thickness and burn quickly in the 
OGS boiler. For comparison, $90 \%$ of the pulverized coal leaving the coal mills passes through a 200-mesh screen.

Table 2.4 - Switchgrass Size Distribution

\begin{tabular}{|c|r|r|r|}
\hline & \multicolumn{3}{|c|}{ \% Retained } \\
\hline Mesh Size & Coal & Switchgrass & Nodes \\
\hline$>3$ & & 0.75 & 4.69 \\
\hline $3-48$ & & 86.01 & 94.61 \\
\hline $48-200$ & & 10.94 & 0.68 \\
\hline $200-325$ & 13.59 & 1.17 & 0.02 \\
\hline $325-400$ & 22.96 & 0.35 & 0.00 \\
\hline$<400$ & 57.47 & 0.78 & 0.00 \\
\hline
\end{tabular}

During co-fire testing, several samples were taken to determine the bulk densities of the switchgrass at different points in the system. This information is important for the design of rotary airlocks, screw conveyors, belt conveyors, and surge bins. The density measurements varied with not only time, but also with who was conducting the testing. It was difficult to get representative samples from the debaler because of the low density. For the baghouse samples, the material quickly settled to a higher density after sampling. For these reasons, a range of bulk densities is given in Table 2.5. The ground switchgrass settled over time, explaining the high bulk density measured for the sample taken from the truck that was used for switchgrass storage during startup. The estimated bale densities are included for comparison. The explanation for the higher bulk densities after grinding is that the smaller particles of switchgrass fill in the spaces between the larger pieces, which results in a higher bulk density.

Table 2.5 - Bulk Switchgrass Densities

\begin{tabular}{|l|l|c|c|c|c|c|c|}
\hline & & $\mathbf{3 x 3}$ & $\mathbf{3 x 4}$ & Debaler & Baghouse & Truck & Nodes \\
\hline Bulk Density & $\mathrm{lb} / \mathrm{ft}^{3}$ & 9.7 & 10.4 & $1.3-4.0$ & $6.7-15.6$ & 14.3 & $13.8-18.3$ \\
\hline Bulk Density & $\mathrm{kg} / \mathrm{m}^{3}$ & 156 & 167 & $21-64$ & $107-250$ & 229 & $221-293$ \\
\hline
\end{tabular}

\subsection{Stack Testing}

To meet Iowa Department of Natural Resources requirements, two days of stack testing were conducted. On November 15, 2000, baseline coal-only stack testing was performed to collect data on carbon monoxide and particulate emissions. Each day of stack testing consisted of three tests, each approximately one hour in length. During this time the coal and switchgrass flows were measured precisely. This supplemented the continuous emissions monitoring (CEM) data, which included $\mathrm{SO}_{2}, \mathrm{NO}_{\mathrm{x}}$, and opacity measurements. At the same time, an Orsat portable gas analyzer was used to sample $\mathrm{NO}_{\mathrm{x}}, \mathrm{CO}, \mathrm{CO}_{2}$, and $\mathrm{O}_{2}$ levels.

Stack testing was performed when co-firing switchgrass on December 20, 2000. Unfortunately, during the co-fire stack testing there was a problem with the OGS boiler, unrelated to the co-fire testing, which caused abnormally high $\mathrm{CO}$ readings. The night before the stack testing, the boiler operators noticed "sparklers" leaving the boiler when burning only coal, indicating incomplete combustion. In addition, the operating team didn't soot blow the night before testing, 
resulting in abnormally high ESP temperatures during the following day's testing. The co-fire stack testing results have been included in Table 2.6 for completeness, but it should be emphasized that the results do not represent typical boiler performance when co-firing. There were also some questions about the reported reduction in particulate emissions during co-firing. While this is a desired result, the reduction was due almost entirely to a drop in the condensable particulate measurements, which is not an expected result. The particulate emissions from the baseline, coal-only testing had initially been processed incorrectly, so we are skeptical of these results as well. Note that the co-fire emissions in Table 2.6 include the heat of combustion for the switchgrass.

Table 2.6 - Base-line and Co-fire Stack Test Results

\begin{tabular}{|l|r|r|r|r|r|r|r|r|}
\hline & $\begin{array}{c}\text { Coal } \\
\text { Flow }\end{array}$ & $\begin{array}{c}\text { Switchgrass } \\
\text { Flow }\end{array}$ & \multicolumn{1}{c|}{ SO2 } & \multicolumn{1}{c|}{ NOx } & \multicolumn{1}{c|}{ PM } & \multicolumn{1}{c|}{ PM10 } & \multicolumn{1}{c|}{ Co } & \multicolumn{1}{c|}{ Load } \\
\hline & (ton/h) & \multicolumn{1}{c|}{ (ton/h) } & (Ib/MM Btu) & (Ib/MM Btu) & (Ib/MM Btu) & (Ib/MM Btu) & (lb/MM Btu) & $(\mathrm{MW})$ \\
\hline Base-Line & 460 & 0.0 & 0.654 & 0.352 & 0.089 & 0.085 & 0.0004 & 711 \\
\hline Co-Firing & 444 & 3.8 & 0.656 & 0.394 & 0.046 & 0.040 & 0.0043 & 712 \\
\hline
\end{tabular}

\subsection{Orsat Gas Analyzer Results}

On specific test days, an Orsat portable gas analyzer was used to collect data to supplement the CEM results. The Orsat meter recorded $\mathrm{NO}_{\mathrm{x}}, \mathrm{CO}, \mathrm{CO}_{2}$, and $\mathrm{O}_{2}$ levels leaving the economizer, entering the air heater, and exiting the air heater. Readings were taken for both the east and west sides of the boiler. The Orsat data included three days of baseline, coal-only data. The Orsat readings verified that there were abnormally high $\mathrm{CO}$ levels during the co-fire stack testing on December 20, but the readings also show that the switchgrass did not normally contribute to higher $\mathrm{CO}$ readings. Table 2.7 shows the average gas analyzer readings for several test days. Note that the co-fire rates in January were 3 to 5 times higher than those in December.

Table 2.7 - Orsat Gas Analyzer Results (ppm)

\begin{tabular}{|l|r|r|r|r|r|r|}
\hline Date & $\mathbf{1 5 - N o v - 0 0}$ & $\mathbf{8 - D e c - 0 0}$ & 20-Dec-00 & 15-Jan-01 & 16-Jan-01 & $\mathbf{1 7 - J a n - 0 1}$ \\
\hline Fuel & Coal Only & Coal Only & Coal/SWG & Coal/SWG & Coal/SWG & Coal Only \\
\hline CO-Economizer Outlet & $\mathbf{1 . 1}$ & $\mathbf{2 . 3}$ & 15.9 & 0.9 & 0.9 & $\mathbf{0 . 0}$ \\
\hline CO-Air Heater Outlet & $\mathbf{0 . 9}$ & $\mathbf{2 . 3}$ & 15.0 & 1.6 & 4.2 & $\mathbf{0 . 5}$ \\
\hline & & & & & & \\
\hline NOx-Economizer Outlet & $\mathbf{2 1 8}$ & $\mathbf{2 5 8}$ & 243 & 218 & 193 & $\mathbf{2 3 2}$ \\
\hline NOx-Air Heater Outlet & $\mathbf{1 7 7}$ & $\mathbf{1 9 9}$ & 221 & 217 & 206 & $\mathbf{1 7 8}$ \\
\hline
\end{tabular}

Note: Numbers in bold are baseline coal-only measurements.

\begin{tabular}{|l|r|r|r|r|r|}
\hline Date & 19-Jan-01 & 22-Jan-01 & 23-Jan-01 & 24-Jan-01 & 25-Jan-01 \\
\hline Fuel & Coal/SWG & Coal/SWG & Coal/SWG & Coal/SWG & Coal/SWG \\
\hline CO-Economizer Outlet & 0.1 & 0.4 & 1.1 & 1.1 & 0.6 \\
\hline CO-Air Heater Outlet & 0.4 & 0.8 & 1.1 & 1.5 & 1.3 \\
\hline & & & & & \\
\hline NOx-Economizer Outlet & 219 & 277 & 255 & 269 & 203 \\
\hline NOx-Air Heater Outlet & 166 & 213 & 203 & 207 & 158 \\
\hline
\end{tabular}




\subsection{Continuous Emissions Monitoring Results}

The continuous emission monitoring equipment at OGS records $\mathrm{SO}_{2}, \mathrm{NO}_{\mathrm{x}}$, and opacity levels leaving the stack. The system records information continuously and it is apparent from examining the details of the raw data that major changes up or down in fuel flow result in large changes in emissions during the transition period. Table 2.8 shows the average daily $\mathrm{SO}_{2}, \mathrm{NO}_{\mathrm{x}}$, and opacity levels for the month of January, as recorded by the CEM system. Bold numbers indicate days when only coal was being burned. The data from January is of the most interest because the equipment redesign had been completed, so the switchgrass system could be operated at rates of over 15 ton/h (13.6 tonne/h). Data from January 4, 2001, were excluded from the averages due to abnormal boiler operation.

Table 2.8 - CEM Data for January 2001

\begin{tabular}{|c|c|c|c|c|}
\hline Date & $\mathrm{SO} 2$ & NOx & Opacity & Oxygen \\
\hline & (ppm) & $(\mathrm{ppm})$ & $(\%)$ & $(\%)$ \\
\hline 1-Jan-01 & 262 & 164 & 16.5 & 6.03 \\
\hline 2-Jan-01 & 248 & 181 & 16.3 & 5.93 \\
\hline 3-Jan-01 & 235 & 189 & 17.0 & 5.95 \\
\hline 4-Jan-01* & 175 & 128 & 32.2 & 8.41 \\
\hline 5-Jan-01 & 229 & 164 & 17.6 & 6.12 \\
\hline 6-Jan-01 & 227 & 169 & 16.0 & 6.17 \\
\hline 7-Jan-01 & 227 & 170 & 14.5 & 6.29 \\
\hline 8-Jan-01 & 236 & 179 & 14.7 & 6.12 \\
\hline 9-Jan-01 & 262 & 172 & 17.3 & 5.93 \\
\hline 10-Jan-01 & 241 & 179 & 16.3 & 6.09 \\
\hline 11-Jan-01 & 262 & 202 & 18.6 & 6.02 \\
\hline 12-Jan-01 & 247 & 197 & 16.0 & 6.00 \\
\hline 13-Jan-01 & 253 & 180 & 17.2 & 6.01 \\
\hline 14-Jan-01 & 255 & 188 & 17.5 & 6.09 \\
\hline 15-Jan-01 & 241 & 189 & 17.1 & 6.21 \\
\hline 16-Jan-01 & 248 & 199 & 15.8 & 6.08 \\
\hline 17-Jan-01 & 257 & 182 & 17.0 & 6.02 \\
\hline 18-Jan-01 & 255 & 171 & 17.9 & 6.07 \\
\hline 19-Jan-01 & 252 & 176 & 16.5 & 5.97 \\
\hline 20-Jan-01 & 255 & 176 & 15.6 & 6.23 \\
\hline 21-Jan-01 & 246 & 177 & 16.6 & 7.43 \\
\hline 22-Jan-01 & 251 & 214 & 16.3 & 6.61 \\
\hline 23-Jan-01 & 243 & 208 & 16.4 & 6.13 \\
\hline 24-Jan-01 & 239 & 199 & 16.1 & 6.22 \\
\hline 25-Jan-01 & 249 & 150 & 14.9 & 6.42 \\
\hline Average* $^{*}$ & 246.7 & 182 & 16.48 & 6.17 \\
\hline Coal Only* & 247.8 & 176 & 16.58 & 6.19 \\
\hline Co-Firing & 245.7 & 187 & 16.41 & 6.15 \\
\hline
\end{tabular}

*Several boiler trips occurred on January 4, so these data were not included in the averages. 
Because of the variations in emissions caused by weather, fouling, and changes in boiler operation from day-to-day, it is also useful to compare the distributions of $\mathrm{SO}_{2}, \mathrm{NO}_{\mathrm{x}}$, and opacity to see the overall effect of co-firing. Figure 2.1 shows a slight decrease in average daily $\mathrm{SO}_{2}$ emissions when co-firing switchgrass, as expected. Figure 2.2 compares the $\mathrm{NO}_{\mathrm{x}}$ emissions when co-firing with the coal-only values, and there appears to be an increase in $\mathrm{NO}_{\mathrm{x}}$ emissions, although the spread in the data indicates that the boiler was also less stable when running switchgrass. This is true because the switchgrass system was not always consistent in supplying switchgrass to the boiler so the coal flow ramped up and down in response to the changes in switchgrass flow. It is also important to understand that co-firing occurred mostly during the week, when the boiler was running at full capacity, and many of the non-co-fire, coal-only days were weekends when the boiler was running at reduced load. Because both $\mathrm{NO}_{\mathrm{x}}$ and $\mathrm{SO}_{2}$ emissions increase with load, part of the increased emissions in Table 2.8 and in Figure 2.2 are due to the higher loads. Figure 2.3 shows that the opacity was virtually unchanged when burning switchgrass.

\section{Figure 2.1 - Comparison of $\mathrm{SO}_{2}$ Emissions when Co-Firing}

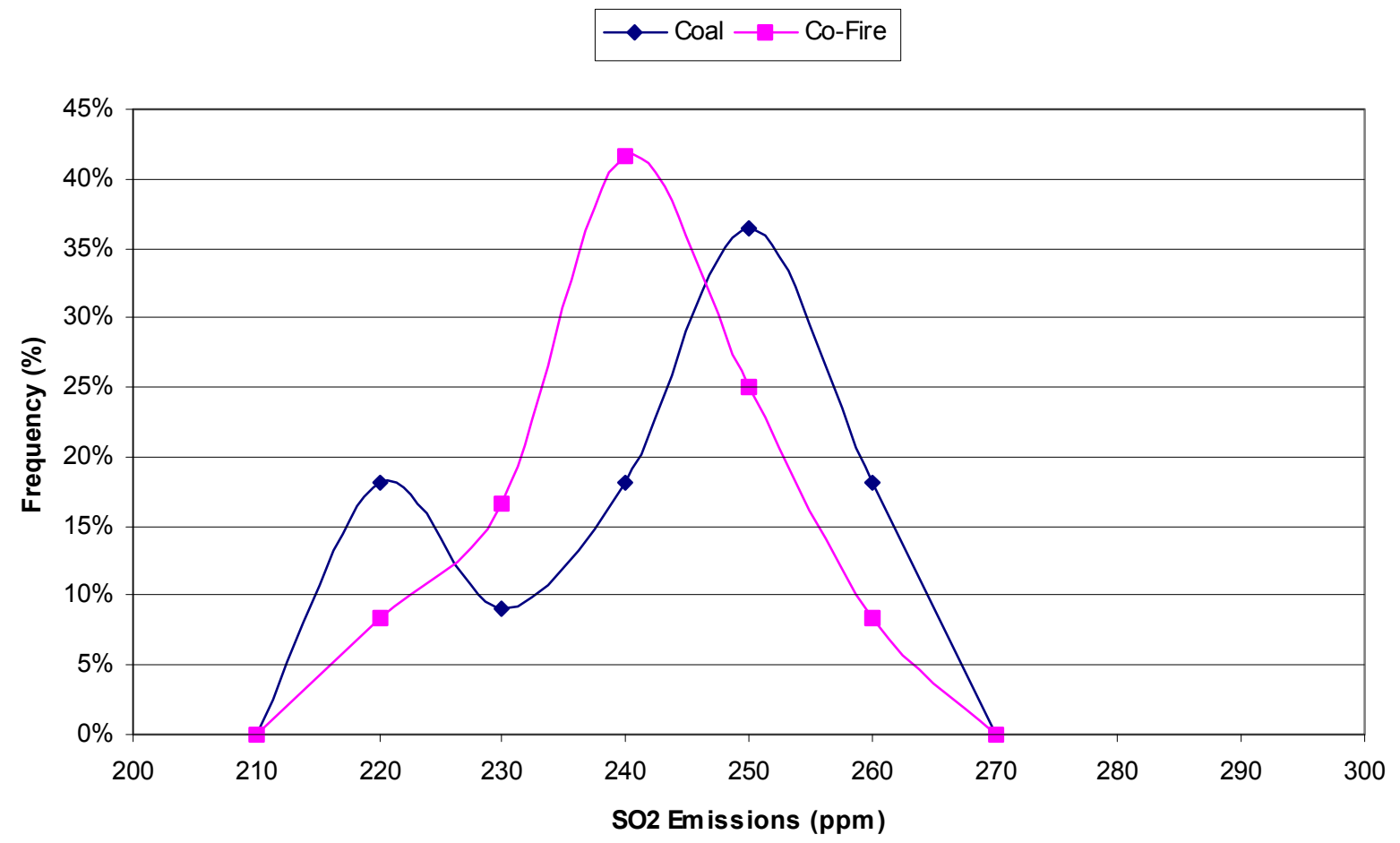


Figure 2.2 - Comparison of $\mathrm{NO}_{\mathrm{x}}$ Emissions when Co-Firing

$$
\rightarrow \text { Coal }- \text { - Co-Fire }
$$

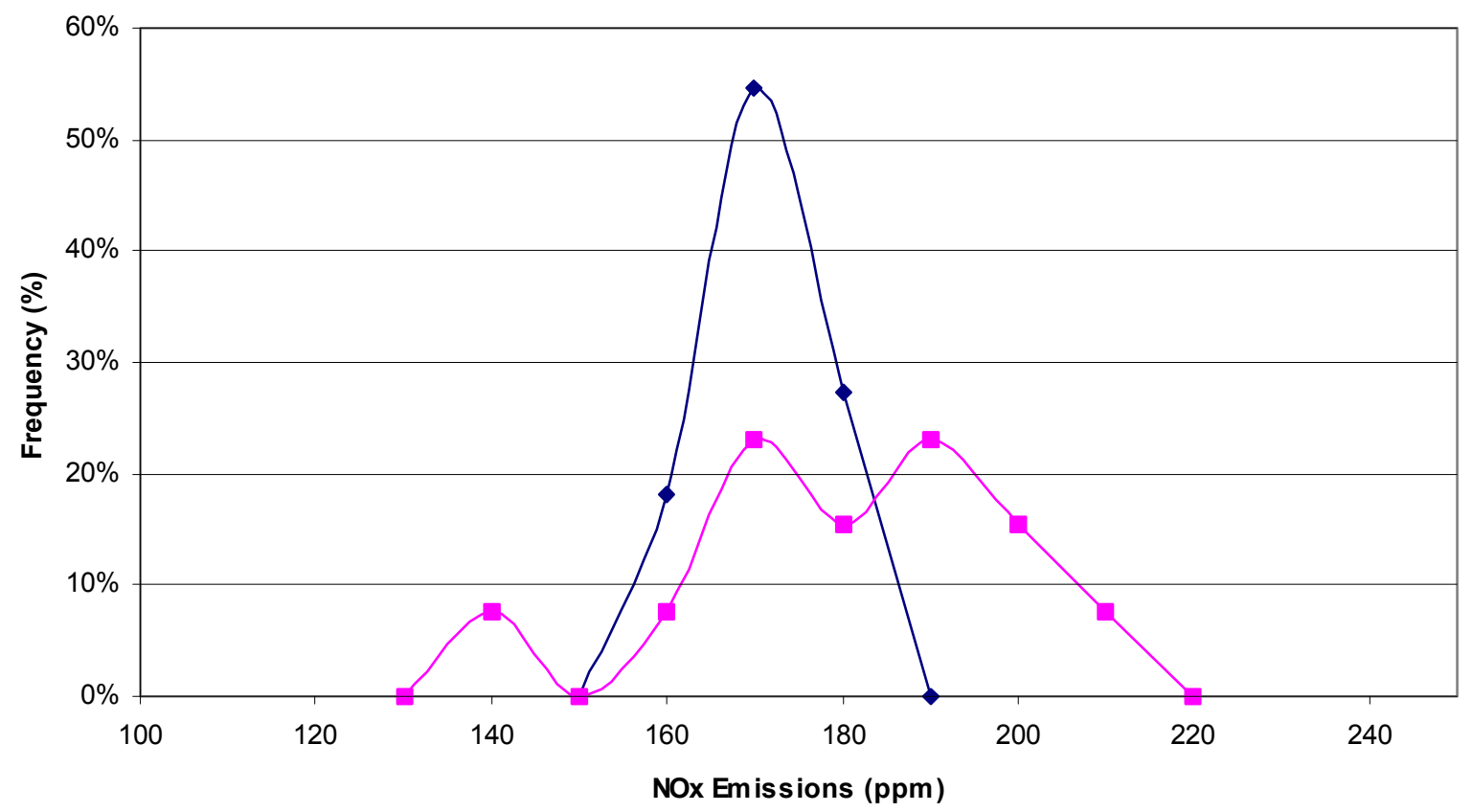

Figure 2.3 - Comparison of Opacity when Co-Firing

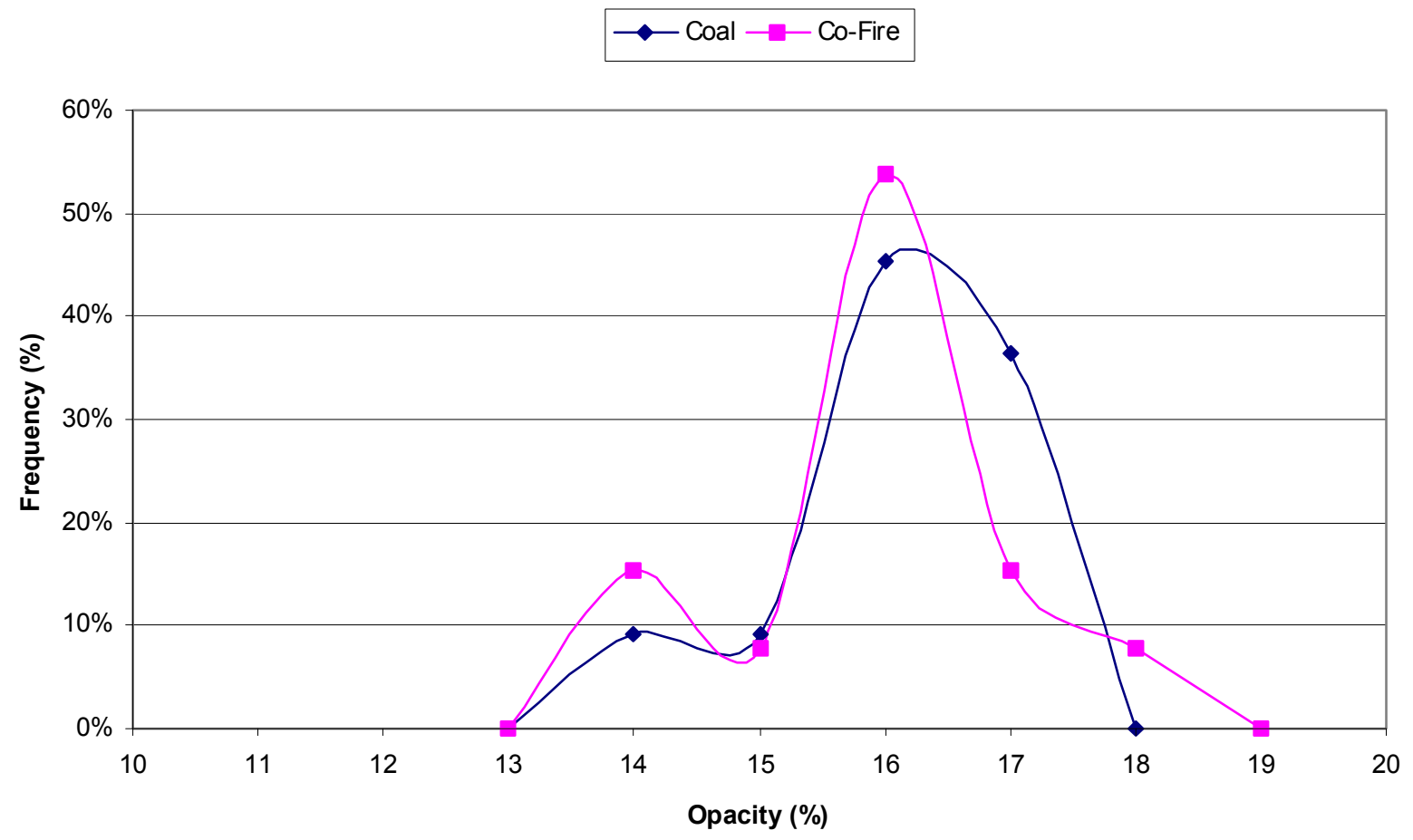




\subsection{Sampling and Ash Analysis}

The following samples were collected during selected "test days" during the two-month co-fire campaign:

1). Raw coal feed

2). Pulverized coal feed

3). Raw switchgrass feed

4). Chopped switchgrass feed

5). Switchgrass nodes

6). Boiler bottom ash

7). Boiler bottom ash water

8). Economizer ash (east and west sides of boiler)

9). Fly ash (east and west sides of boiler, hoppers B, D \& F)

One reason for testing both the raw coal and the pulverized coal is because soda ash is sometimes added to the coal to optimize ESP performance. All of the raw coal samples were collected before soda ash addition. The pulverized coal also showed some changes in composition, possibly due to the high temperature of the primary combustion air. The complete analysis of the bulk coal, before soda ash addition, is given in Section 2.1 of this report.

For the switchgrass, three sets of samples were collected. The debaler sample-pulled from either the inlet conveyor or the discharge chute of the debaler-was the most representative of the switchgrass entering the plant. The second sample point for the switchgrass was downstream of the Eliminator. During December, chopped switchgrass samples were collected from the exit of the Eliminator; during January, samples were collected from the baghouse discharge. With the addition of the suction line to the Eliminator discharge, it became possible to capture a large fraction of switchgrass nodes for analysis. The thought was that if the nodes proved to be a source of high silica or high alkali, it might be desirable to remove them from the fuel stream, but this was not the case. The fuel analyses of the debaler samples and the switchgrass nodes are given in Section 2.1.

Economizer and fly ash samples were collected from both the east and west sides of the boiler. (Switchgrass was injected into the east fireball.) For the fly ash, samples were collected from the corresponding sequences of three ash hoppers on each side of the boiler. The flue gases passed through six ESP fields, with every two fields emptying into a fly ash hopper. This meant that three samples were collected from the east side of the boiler and three samples from the west side. The inlet hopper for each side was labeled sample B, with hopper D in the middle, and hopper F on the outlet side of the ESP. In some cases, no sample could be collected from the outlet hopper $\mathrm{F}$ because the ESP was operating too efficiently. Table 2.9 has the average fly ash composition data for coal-only conditions. Table 2.10 has the data from the same hoppers during co-firing. 
Table 2.9 - Fly Ash Data for Baseline Coal-Only Conditions

\begin{tabular}{|c|c|c|c|c|c|c|c|}
\hline Fireball & & East & East & East & West & West & West \\
\hline Hopper & & Inlet & Middle & Outlet & Inlet & Middle & Outlet \\
\hline Fuel & & Coal Only & Coal Only & Coal Only & Coal Only & Coal Only & Coal Only \\
\hline LOI & $\%$ & 0.49 & 0.48 & & 0.44 & 0.44 & 0.91 \\
\hline $\mathrm{Na}-\mathrm{Na} 2 \mathrm{O}$ & $\%$ & 0.091 & 0.134 & & 0.094 & 0.132 & 0.248 \\
\hline K-K2O & $\%$ & 0.011 & 0.011 & & 0.011 & 0.013 & 0.016 \\
\hline SiO2 & $\%$ & 38.33 & 34.43 & & 38.41 & 33.06 & 30.03 \\
\hline $\mathrm{Al} 2 \mathrm{O} 3$ & $\%$ & 22.36 & 22.83 & & 22.87 & 22.24 & 23.44 \\
\hline TiO2 & $\%$ & 1.58 & 1.51 & & 1.41 & 1.46 & 1.38 \\
\hline $\mathrm{Fe} 2 \mathrm{O} 3$ & $\%$ & 5.71 & 5.62 & & 4.88 & 5.46 & 5.20 \\
\hline $\mathrm{CaO}$ & $\%$ & 22.70 & 24.45 & & 22.15 & 24.25 & 24.10 \\
\hline $\mathrm{MgO}$ & $\%$ & 4.13 & 4.41 & & 4.05 & 4.73 & 4.41 \\
\hline $\mathrm{Na} 2 \mathrm{O}$ & $\%$ & 2.36 & 2.48 & & 2.38 & 2.48 & 2.55 \\
\hline K2O & $\%$ & 0.47 & 0.47 & & 0.49 & 0.49 & 0.50 \\
\hline P2O5 & $\%$ & 1.52 & 2.00 & & 1.56 & 2.00 & 2.63 \\
\hline $\mathrm{SO} 3$ & $\%$ & 0.88 & 1.20 & & 0.66 & 1.55 & 2.13 \\
\hline $\mathrm{Cl}$ & $\%$ & $<0.01$ & $<0.01$ & & $<0.01$ & $<0.01$ & $<0.01$ \\
\hline $\mathrm{CO} 2$ & $\%$ & 0.03 & 0.04 & & 0.08 & 0.03 & 0.03 \\
\hline As & $\mathrm{mg} / \mathrm{kg}$ & 22.3 & 23.95 & & 23.1 & 26.7 & 31.1 \\
\hline $\mathrm{Ba}$ & $\mathrm{mg} / \mathrm{kg}$ & 5,550 & 6,175 & & 5,570 & 6,365 & 7,610 \\
\hline $\mathrm{Cr}$ & $\mathrm{mg} / \mathrm{kg}$ & 92 & 100.5 & & 92.5 & 101 & 80 \\
\hline $\mathrm{Cd}$ & $\mathrm{mg} / \mathrm{kg}$ & 1.3 & 1.95 & & 1.45 & 2.15 & 2.7 \\
\hline $\mathrm{Pb}$ & $\mathrm{mg} / \mathrm{kg}$ & 47 & 64 & & 47 & 67 & 88 \\
\hline $\mathrm{Hg}$ & $\mathrm{mg} / \mathrm{kg}$ & $<0.1$ & $<0.1$ & & $<0.1$ & $<0.1$ & $<0.1$ \\
\hline $\mathrm{Ag}$ & $\mathrm{mg} / \mathrm{kg}$ & $<1$ & $<1$ & & $<1$ & $<1$ & $<1$ \\
\hline $\mathrm{Se}$ & $\mathrm{mg} / \mathrm{kg}$ & 8 & 10 & & 6 & 10.5 & 13 \\
\hline
\end{tabular}


Table 2.10 - Fly Ash Data from Co-Firing

\begin{tabular}{|c|c|c|c|c|c|c|c|}
\hline Fireball & & East & East & East & West & West & West \\
\hline Hopper & & Inlet & Middle & Outlet & Inlet & Middle & Outlet \\
\hline Fuel & & Coal/SWG & Coal/SWG & Coal/SWG & Coal/SWG & Coal/SWG & Coal/SWG \\
\hline LOI & $\%$ & 0.37 & 0.18 & 0.27 & 0.25 & 0.29 & 0.37 \\
\hline $\mathrm{Na}-\mathrm{Na} 2 \mathrm{O}$ & $\%$ & 0.128 & 0.177 & 0.354 & 0.138 & 0.191 & 0.320 \\
\hline K-K2O & $\%$ & 0.013 & 0.010 & 0.017 & 0.013 & 0.016 & 0.015 \\
\hline $\mathrm{SiO} 2$ & $\%$ & 36.73 & 34.01 & 2807 & 3736 & 3351 & 29.03 \\
\hline $\mathrm{Al} 2 \mathrm{O} 3$ & $\%$ & 22.88 & 22.20 & 22.88 & 22.26 & 23.33 & 22.84 \\
\hline TiO2 & $\%$ & 1.50 & 1.44 & 1.36 & 1.44 & 1.38 & 1.42 \\
\hline $\mathrm{Fe} 2 \mathrm{O} 3$ & $\%$ & 5.63 & 5.56 & 5.39 & 5.62 & 5.46 & 5.27 \\
\hline $\mathrm{CaO}$ & $\%$ & 22.33 & 22.97 & 24.70 & 21.07 & 22.83 & 24.20 \\
\hline $\mathrm{MgO}$ & $\%$ & 4.17 & 4.26 & 4.66 & 3.93 & 4.21 & 4.59 \\
\hline $\mathrm{Na} 2 \mathrm{O}$ & $\%$ & 2.57 & 2.64 & 2.81 & 2.47 & 2.67 & 2.78 \\
\hline $\mathrm{K} 2 \mathrm{O}$ & $\%$ & 0.57 & 0.54 & 0.48 & 0.62 & 0.61 & 0.54 \\
\hline P2O5 & $\%$ & 1.72 & 2.03 & 2.76 & 1.68 & 1.98 & 2.70 \\
\hline SO3 & $\%$ & 0.69 & 0.84 & 2.43 & 0.98 & 1.31 & 2.91 \\
\hline $\mathrm{Cl}$ & $\%$ & $<0.01$ & $<0.01$ & $<0.01$ & $<0.01$ & $<0.01$ & $<0.01$ \\
\hline $\mathrm{CO} 2$ & $\%$ & 0.08 & 0.09 & 0.07 & 0.09 & 0.06 & 0.09 \\
\hline As & $\mathrm{mg} / \mathrm{kq}$ & 24.6 & 27.6 & 36.6 & 24.1 & 25.8 & 33.6 \\
\hline $\mathrm{Ba}$ & $\mathrm{mg} / \mathrm{kg}$ & 5,613 & 6,190 & 7,545 & 5,570 & 5,963 & 7,323 \\
\hline $\mathrm{Cr}$ & $\mathrm{mg} / \mathrm{kg}$ & 79 & 90 & 89 & 79 & 85 & 91 \\
\hline $\mathrm{Cd}$ & $\mathrm{mg} / \mathrm{kg}$ & 1.4 & 1.8 & 2.9 & 1.6 & 1.7 & 2.6 \\
\hline $\mathrm{Pb}$ & $\mathrm{mg} / \mathrm{kg}$ & 49 & 61 & 86 & 47 & 62 & 79 \\
\hline $\mathrm{Hg}$ & $\mathrm{mg} / \mathrm{kg}$ & $<0.1$ & $<0.1$ & $<0.1$ & $<0.1$ & $<0.1$ & $<0.1$ \\
\hline $\mathrm{Ag}$ & $\mathrm{mg} / \mathrm{kg}$ & $<1$ & $<1$ & $<1$ & $<1$ & $<1$ & $<1$ \\
\hline $\mathrm{Se}$ & $\mathrm{mg} / \mathrm{kg}$ & 8 & 11 & 12 & 5 & 8 & 13 \\
\hline
\end{tabular}

Bottom ash samples were collected from the discharge pipe to the OGS ash pond. The water from the ash pond is recirculated to the boiler and re-used for sluicing bottom ash and economizer ash, as well as supplying seal water for the bottom of the top-hung boiler. Samples of the bottom ash water were collected separately from the bottom ash itself to measure sodium, potassium, and trace elements that may have leached out of the ash. Economizer ash samples were collected for the extreme east and extreme west ash hoppers at the bottom of the economizer section. All ash hoppers were emptied after co-firing was started to assure all ash collected was from co-fire periods. Table 2.11 contains the economizer ash analysis when burning coal only and when co-firing. Table 2.12 contains the same data for the bottom ash, reported on a dry basis. Table 2.13 contains the RCRA trace element, sodium, and potassium analyses of the bottom ash water. 
Table 2.11 - Economizer Ash Analysis

\begin{tabular}{|l|l|r|r|r|r|}
\hline Fireball & & \multicolumn{1}{l|}{ East } & \multicolumn{1}{l|}{ West } & East & West \\
\hline Fuel & & Coal Only & Coal Only & Coal/SWG & Coal/SWG \\
\hline & & & & & \\
\hline $\mathrm{LOI}$ & $\%$ & $\mathbf{0 . 2 2}$ & $\mathbf{0 . 2 9}$ & 0.11 & 0.71 \\
\hline $\mathrm{Na}-\mathrm{Na} 2 \mathrm{O}$ & $\%$ & $\mathbf{0 . 0 6 4}$ & $\mathbf{0 . 0 4 1}$ & 0.059 & 0.052 \\
\hline $\mathrm{K}-\mathrm{K} 2 \mathrm{O}$ & $\%$ & $\mathbf{0 . 0 1 3}$ & $\mathbf{0 . 0 0 6}$ & 0.009 & 0.009 \\
\hline & & & & & \\
\hline $\mathrm{SiO} 2$ & $\%$ & $\mathbf{4 0 . 7 1}$ & $\mathbf{3 9 . 0 6}$ & 37.83 & 38.69 \\
\hline $\mathrm{Al2O} 3$ & $\%$ & $\mathbf{2 1 . 9 3}$ & $\mathbf{2 2 . 1 1}$ & 21.66 & 21.22 \\
\hline $\mathrm{TiO} 2$ & $\%$ & $\mathbf{1 . 5 1}$ & $\mathbf{1 . 5 6}$ & 1.48 & 1.49 \\
\hline $\mathrm{Fe} 2 \mathrm{O} 3$ & $\%$ & $\mathbf{5 . 7 5}$ & $\mathbf{5 . 8 7}$ & 5.64 & 5.74 \\
\hline $\mathrm{CaO}$ & $\%$ & $\mathbf{2 1 . 8 0}$ & $\mathbf{2 1 . 9 0}$ & 22.13 & 21.23 \\
\hline $\mathrm{MgO}$ & $\%$ & $\mathbf{3 . 9 0}$ & $\mathbf{3 . 9 9}$ & 4.00 & 3.86 \\
\hline $\mathrm{Na} 2 \mathrm{O}$ & $\%$ & $\mathbf{1 . 8 7}$ & $\mathbf{1 . 8 5}$ & 1.97 & 1.95 \\
\hline $\mathrm{K} 2 \mathrm{O}$ & $\%$ & $\mathbf{0 . 4 4}$ & $\mathbf{0 . 4 1}$ & 0.57 & 0.49 \\
\hline $\mathrm{P} 2 \mathrm{O} 5$ & $\%$ & $\mathbf{1 . 3 3}$ & $\mathbf{1 . 3 3}$ & 1.43 & 1.50 \\
\hline $\mathrm{SO} 3$ & $\%$ & $\mathbf{1 . 7 9}$ & $\mathbf{1 . 6 6}$ & 2.02 & 1.68 \\
\hline $\mathrm{Cl}$ & $\%$ & $<\mathbf{0 . 0 1}$ & $<\mathbf{0 . 0 1}$ & $<0.01$ & $<0.01$ \\
\hline $\mathrm{CO} 2$ & $\%$ & $\mathbf{0 . 0 2}$ & $\mathbf{0 . 0 3}$ & 0.12 & 0.11 \\
\hline & & & & & \\
\hline $\mathrm{As}$ & $\mathrm{mg} / \mathrm{kg}$ & $\mathbf{1 6 . 5}$ & $\mathbf{1 6 . 2}$ & 20.3 & 17.5 \\
\hline $\mathrm{Ba}$ & $\mathrm{mg} / \mathrm{kg}$ & $\mathbf{5 , 2 1 5}$ & $\mathbf{5 , 2 3 5}$ & 5,097 & 4,930 \\
\hline $\mathrm{Cr}$ & $\mathrm{mg} / \mathrm{kg}$ & $\mathbf{8 8}$ & $\mathbf{8 9}$ & 83 & 85 \\
\hline $\mathrm{Cd}$ & $\mathrm{mg} / \mathrm{kg}$ & $\mathbf{3 . 4}$ & $\mathbf{1 . 4}$ & 3.3 & 2.3 \\
\hline $\mathrm{Pb}$ & $\mathrm{mg} / \mathrm{kg}$ & $\mathbf{2 9}$ & $\mathbf{2 9}$ & 26 & 28 \\
\hline $\mathrm{Hg}$ & $\mathrm{mg} / \mathrm{kg}$ & $<\mathbf{0 . 1}$ & $<\mathbf{0 . 1}$ & $<0.1$ & $<0.1$ \\
\hline $\mathrm{Ag}$ & $\mathrm{mg} / \mathrm{kg}$ & $<1$ & $<1$ & $<1$ \\
\hline $\mathrm{Se}$ & $\mathrm{mg} / \mathrm{kg}$ & $<\mathbf{2}$ & $<2$ & $<2$ \\
\hline & & & & & \\
\hline
\end{tabular}


Table 2.12 - Bottom Ash Analysis

\begin{tabular}{|l|l|r|r|}
\hline Fuel & & Coal Only & Coal/SWG \\
\hline & & & \\
\hline $\mathrm{LOI}$ & $\%$ & $\mathbf{0 . 6 4}$ & 0.56 \\
\hline $\mathrm{Na}-\mathrm{Na} 2 \mathrm{O}$ & $\%$ & $\mathbf{0 . 0 4 8}$ & 0.042 \\
\hline $\mathrm{K}-\mathrm{K} 2 \mathrm{O}$ & $\%$ & $\mathbf{0 . 0 1 4}$ & 0.014 \\
\hline & & & \\
\hline $\mathrm{SiO} 2$ & $\%$ & $\mathbf{4 6 . 8 2}$ & 45.69 \\
\hline $\mathrm{Al} 2 \mathrm{O} 3$ & $\%$ & $\mathbf{2 0 . 1 6}$ & 20.90 \\
\hline $\mathrm{TiO} 2$ & $\%$ & $\mathbf{1 . 4 7}$ & 1.36 \\
\hline $\mathrm{Fe} 2 \mathrm{O} 3$ & $\%$ & $\mathbf{5 . 8 4}$ & 5.56 \\
\hline $\mathrm{CaO}$ & $\%$ & $\mathbf{1 9 . 0 5}$ & 17.89 \\
\hline $\mathrm{MgO}$ & $\%$ & $\mathbf{3 . 5 4}$ & 3.38 \\
\hline $\mathrm{Na} 2 \mathrm{O}$ & $\%$ & $\mathbf{1 . 5 3}$ & 1.74 \\
\hline $\mathrm{K} 2 \mathrm{O}$ & $\%$ & $\mathbf{0 . 5 4}$ & 0.80 \\
\hline $\mathrm{P} 2 \mathrm{O} 5$ & $\%$ & $\mathbf{1 . 1 7}$ & 1.30 \\
\hline $\mathrm{SO} 3$ & $\%$ & $\mathbf{0 . 2 0}$ & 0.33 \\
\hline $\mathrm{Cl}$ & $\%$ & $<0.01$ & $<0.01$ \\
\hline $\mathrm{CO} 2$ & $\%$ & $\mathbf{0 . 0 6}$ & 0.16 \\
\hline & & & \\
\hline $\mathrm{As}$ & $\mathrm{mg} / \mathrm{kg}$ & $\mathbf{3 . 9}$ & 5.2 \\
\hline $\mathrm{Ba}$ & $\mathrm{mg} / \mathrm{kg}$ & $\mathbf{4 , 6 2 0}$ & 4,428 \\
\hline $\mathrm{Cr}$ & $\mathrm{mg} / \mathrm{kg}$ & $\mathbf{1 0 5}$ & 68 \\
\hline $\mathrm{Cd}$ & $\mathrm{mg} / \mathrm{kg}$ & $<\mathbf{0 . 5}$ & $<0.5$ \\
\hline $\mathrm{Pb}$ & $\mathrm{mg} / \mathrm{kg}$ & $\mathbf{8}$ & 10 \\
\hline $\mathrm{Hg}$ & $\mathrm{mg} / \mathrm{kg}$ & $<\mathbf{0 . 1}$ & $<0.1$ \\
\hline $\mathrm{Ag}$ & $\mathrm{mg} / \mathrm{kg}$ & $<1$ & $<1$ \\
\hline $\mathrm{Se}$ & $\mathrm{mg} / \mathrm{kg}$ & $<2$ & $<2$ \\
\hline & & & \\
\hline
\end{tabular}

Table 2.13 - Analysis of Bottom Ash Water

\begin{tabular}{|l|l|r|r|}
\hline Fuel & & Coal Only & Coal/SWG \\
\hline & & & \\
\hline $\mathrm{Na}-\mathrm{Na} 2 \mathrm{O}$ & $\mathrm{mg} / \mathrm{L}$ & $\mathbf{4 2 2 . 5 0 0}$ & 415.000 \\
\hline $\mathrm{K}-\mathrm{K} 2 \mathrm{O}$ & $\mathrm{mg} / \mathrm{L}$ & 39.350 & 49.917 \\
\hline & & & \\
\hline $\mathrm{As}$ & $\mathrm{mg} / \mathrm{L}$ & $\mathbf{0 . 0}$ & 0.0 \\
\hline $\mathrm{Ba}$ & $\mathrm{mg} / \mathrm{L}$ & $<0.001$ & $<0.001$ \\
\hline $\mathrm{Cr}$ & $\mathrm{mg} / \mathrm{L}$ & $<0.04$ & $<0.04$ \\
\hline $\mathrm{Cd}$ & $\mathrm{mg} / \mathrm{L}$ & $<0.01$ & $<0.01$ \\
\hline $\mathrm{Pb}$ & $\mathrm{mg} / \mathrm{L}$ & $<0.1$ & $<0.1$ \\
\hline $\mathrm{Hg}$ & $\mathrm{mg} / \mathrm{L}$ & $<0.005$ & $<0.005$ \\
\hline $\mathrm{Ag}$ & $\mathrm{mg} / \mathrm{L}$ & $<0.04$ & $<0.04$ \\
\hline $\mathrm{Se}$ & $\mathrm{mg} / \mathrm{L}$ & $<0.2$ & $<0.2$ \\
\hline
\end{tabular}




\subsection{EQUIPMENT PERFORMANCE}

As expected with any test program, there were a number of electrical and mechanical problems that interrupted testing. Most of these problems were overcome through changes in operating procedures or through equipment modifications, but in some cases it was determined that equipment modifications would be too expensive or cause excessive delays in the test program.

\subsection{Equipment Modifications \& Repairs}

Section 1.5 of this report describes the switchgrass feed-handling system after several modifications were made during testing. Several pieces of the original equipment were modified or replaced. These changes are outlined in the following sections.

\subsubsection{Debaler}

No major changes were made to the debaler, but initially the gear ratio of the power take-off was changed to achieve a lower idle speed on the tractor. During testing, the teeth on the debaler were periodically sharpened.

\subsubsection{Air Knife}

The air knife used a variable frequency drive to control the blower speed. We initially had problems starting the blower because it had been wired with a motor starter in addition to the variable frequency drive - but only the variable frequency drive was required. The air knife worked well at low feed rates, separating corncobs, rocks, and other material from the lighter switchgrass, but at higher feed rates, the mat of material was too thick for any separation. While metal did not appear to cause any major problems with the Eliminator, we did discover that some metal pieces had been ejected from the inlet chute. There was a small baghouse fire after shutdown one night, which had presumably been caused by a spark from the Eliminator. In one instance, an old tire made it over the air knife and into the Eliminator before causing a plug.

\subsubsection{Debaler-to-Eliminator Conveyor}

To minimize dust from the debaler, a 12 -in. (0.3-m) suction line was attached to a hood over the debaler outlet. Later a second 12 -in. $(0.3-\mathrm{m})$ line was added to the outlet of the hood for additional dust control. In order to operate at the higher flows of 15 tons $/ \mathrm{h}(13.6$ tonne/h), the exit gate on the dust collection hood was increased in size, and 12-in. (0.3-m) sides were added to the belt conveyor so the switchgrass from the debaler wouldn't fall off the sides. At full flow, the mat of switchgrass was $4 \mathrm{ft}(1.2-\mathrm{m})$ wide and more than 12-in. (0.3-m) deep on the belt.

Because the belt was smooth, there was very little friction between the belt and the switchgrass, so there were limits to the angle of inclination of the conveyor. Because of the tendency of the switchgrass to bridge at the inlet chute of the Eliminator, the distance between the end of the conveyor and the inlet chute was adjusted so the switchgrass coming off the belt would fall in an arch and land in the mouth of the Eliminator inlet chute without touching the sides. In future 
designs using belt conveyors, it will be important to be able to adjust the alignment of the belt conveyor and the inlet chute to obtain the proper trajectory of the material into the grinder.

\subsubsection{Eliminator Grinder}

The first problem with the Eliminator was a short circuit in one of the 300-hp (224-kW) motor soft-starts. An insulator on the wiring block had apparently come loose during shipment and was not noticed after installation. During one of the startups, the starter shorted out, burning out a card on the soft-start. A new soft-start was flown in overnight and the entire starter was replaced.

A number of modifications were made to the Eliminator. Initially we could only get about 2 tons $/ \mathrm{h}$ (1.8 tonne/h) through the Eliminator. To increase the throughput, parts of three internal baffles in the Eliminator were removed. These baffles were originally designed to increase the residence time for granular materials, but hindered the flow too much when running switchgrass through the unit. Removing portions of these baffles increased the throughput, so later all of these baffles were cut out. An additional modification was the installation of twisted blades near the inlet of the Eliminator to provide draft to push the material through the grinder. These modifications allowed throughputs approaching 6-7 tons/h (5.4-6.4 tonne/h), with some occasional bridging of the Eliminator inlet chute. Several minor modifications were also made to the inlet chute, including increasing the size of the inlet opening, cutting off the top of the chute to allow lower conveyor angles, and adding a lip to capture dust dropping off the debaler belt conveyor.

The original process design simply dumped material out of the Eliminator onto a textured belt conveyor going up to the surge bin. A hood was used over this belt to control dust, but because the Eliminator produced a slight positive pressure at the outlet, a significant amount of dust blew out from under this hood, and was a major source of dust in the switchgrass processing area. This conveyor - because of the texture - also had some carryover leaving the surge bin, dumping fine material onto the floor below the conveyor. At the end of December, we decided to eliminate this conveyor and pull the entire flow of material through the baghouse. A suction on the inlet resulted, which provided the means of pulling the switchgrass down into the Eliminator, decreasing the frequency of plugs and dramatically increasing the grinder's capacity. This also meant the outlet of the Eliminator was now under negative pressure, so it was no longer a source of dust entering the room. Later, the twisted bars in the Eliminator were reversed to provide some backpressure against the suction, increasing the residence time slightly to give a smaller particle size.

Separation of metals downstream of the Eliminator was easily accomplished once the suction pipe was added because dense materials such as bolts and rocks could not make it up the $30-\mathrm{ft}$ (9-m) section of vertical pipe going to the baghouse. Any debris collected in the pipe was removed each night after shutdown. The velocity through the 26-in. (0.7-m) suction line leaving the Eliminator was estimated at about $30 \mathrm{ft} / \mathrm{s}(9.1 \mathrm{~m} / \mathrm{s})$, which was probably lower than it should have been. At this velocity, a slight decrease in transport air to the Eliminator discharge reduced the velocity enough that the nodes leaving the Eliminator collected in the bottom of the tube, almost filling it in just a few minutes. (Because the transport air intake was at floor level, if two 
people stood in front of the intake, it blocked enough air that the nodes would start to accumulate.) This pointed out an important lesson for the design of switchgrass systems: the minimum transport velocity must be set to transport the nodes, not the bulk switchgrass, which is lighter and less dense. This characteristic of our transport system illustrated that it might also be possible to selectively remove the nodes, if desired, and it allowed us to get relatively clean fractions of nodes for testing.

At one point after removing the top of the Eliminator for modifications, a hot spot developed on the outside casing of the Eliminator. The spot was caused when one of the disks used for dust containment around the shaft started rubbing against the outside housing of the unit. This had been seen during the startup of other Eliminator units, but was a matter of concern because of the combustible switchgrass and high dust levels. We emptied the unit of all combustible material, then ran the Eliminator for several hours without any switchgrass flow to allow the high spot in the casing to wear away, after which we had no further problems.

\subsubsection{Baghouse}

One early problem with the baghouse was that we periodically had what we termed "dust incidents", where the flow from the baghouse would suddenly switch over to a very fine material less than 200 microns in size, which could not be drawn up the screw conveyor. The material could be transported as long as there was some longer material present to trap the dust between the screws, but this fine material — when by itself - could flow like a liquid down the conveyor and out the end, or just sit in the conveyor lifting and dropping as the screw passed under it, resembling someone stirring pudding.

At first we suspected the cleaning arm had jammed, but when we inspected the clean side of the baghouse, the arm was turning freely. After the second such dust incident, we discovered that the gears had been stripped in the gearbox driving the cleaning arm, because oil had not been added to the gearbox after installation. Since no bag cleaning could be accomplished, the dust built up to a critical mass in the baghouse and then dropped all at once, overwhelming the screw conveyor. A new gear was flown in and after rebuilding the gearbox, we had no further dust incidents.

When we increased the solids flow to the baghouse in January, we quickly exceeded the capacity of the original baghouse equipment. As designed, the baghouse necked down to an 18 in. $x 40$ in. $(0.45 \mathrm{~m} \times 1.0 \mathrm{~m})$ opening with a 9 in. $(23 \mathrm{~cm})$ diameter screw conveyor emptying into a 20 in. $(0.5 \mathrm{~m})$ diameter by $15 \mathrm{in} .(0.4 \mathrm{~m})$ long rotary valve. The entire screw and rotary valve assembly was replaced by a larger, custom-built 36-in. (1-m) diameter by 40-in. (1-m) long rotary valve.

\subsubsection{Baghouse Conveyor}

The first problem with the conveyor from the baghouse to the surge bin was a basic one: the rotation on the screw conveyor from the baghouse to the surge bin was not checked before startup. The result was that the switchgrass coming from the baghouse was pushed down to the bottom, closed end of the conveyor, causing the belts to fail on the top drive end. Once the cause of the problem was discovered, the leads were reversed and the belts were replaced. 
There were several times that the screw conveyor from the baghouse to the surge bin became overloaded and burned-off the belts on the drive end, finally burning out the motor itself in one instance. On closer examination of the screw conveyor, we discovered that it had been installed incorrectly. Because of the length of the screw conveyor (35 ft. or $10 \mathrm{~m})$, hanger bearings were required every $10 \mathrm{ft}$. $(3.3 \mathrm{~m})$. At the hanger bearings, the individual sections of screw are supposed to be aligned at $180^{\circ}$ from each other, as if there were an imaginary continuous screw, so that the material can transition smoothly under the hanger bearing. When installed, all three of the joints had been installed incorrectly with two joints lagging by $90^{\circ}$ and one leading by $90^{\circ}$. This meant that at the joints lagging by $90^{\circ}$, material would build up longer than it should before being moved on by the flight on the next screw. Correcting the problem would have required disassembling the screw and then either re-drilling or replacing the stub shafts between the individual flights of the screw. To save time, all sections were instead adjusted to lead by $90^{\circ}$ to minimize problems with the screw conveyor.

Even with proper installation, the screw conveyor appeared to have been undersized for the peak flow from the baghouse, even before we routed the full flow from the Eliminator to it. It is possible that the screw conveyor had been sized to handle the average flow and not the peak flow. Before the start of testing in January, the screw conveyor was replaced with a "tubeveyor", which consisted of a belt conveyor lying in a curved trough supporting the belt. A roller at the upper end drove the belt, and the entire conveyor was enclosed and operating under a slight negative pressure to minimize dust. The lower end was open to allow sampling of the material leaving the baghouse, although this allowed excess air to enter the dust collection system. The tube conveyor operated without any problems.

\subsubsection{Surge Bin}

The surge bin probably was not the best design for our application. While the bin did have diverging sides (wider at the bottom than at the top), there was a pinch point that developed at the front wall of the surge bin where the switchgrass was forced into four openings, just slightly larger than the diameter of the four screws in the bottom of the bin. The switchgrass passed through a short section of tube before emptying into the rotary air locks. The manufacturer said that the equipment was designed for handling grains and soybeans, which don't bridge, and that the tubes were meant to minimize dead spots in the equipment. During our testing, if the switchgrass level built up, trying to move the stack of material forward toward the outlet moved the whole pile of switchgrass up against the front wall, causing the screws to bind and trip out. One possible solution would be to add sheer bars just above the screws to disengage the switchgrass trapped by the screws from the rest of the pile above it. Our solution was to run the surge bin with the feed screws on maximum so we did not build up any significant level of switchgrass in the bin. During switchgrass testing at the Southern Company's Gadsden power plant, they observed similar problems where the switchgrass would bind together and cause large forces to be exerted backwards against the feed screws. They also resorted to running their bin with lower levels of material.

Another problem with our bin design was that there was a dividing wall between the two pairs of feed screws. If the bin had been run as a surge bin with a significant inventory of material, this 
would have been fine, but because we were running in starve-fed mode, the result was uneven distribution of the flow between the two burners. With no dividing wall between the pair of screws, the material could have landed anywhere in the bin and the screws would have leveled the material across the bottom of the bin. With the dividing wall, if the material landed mostly on one side of the bin, it could not get over the divider to the other set of screws going to the other burner. Because the flow leaving the northwest switchgrass burner could not be seen due to its location in the boiler, it was difficult to determine if the flow was being split equally. However, at times, there were small stones traveling through the transport lines and these stones were making a sound in only one of the transport lines, indicating an uneven split in flow.

The entire surge bin was kept under a negative pressure by a 12-in. (0.3-m) suction line attached to the dust collection system. By keeping all of the equipment downstream of the Eliminator under a slight negative pressure, dust levels after the January modifications were minimal.

\subsubsection{Rotary Airlocks}

The rotary airlocks caused continual problems. Their purpose in the system was to transfer the chopped switchgrass from the surge bin at atmospheric pressure, into the pneumatic transport lines going to the boiler, which were operating under several psi $(10 \mathrm{kPa})$ of pressure. They were designed with individual pockets with close tolerances to prevent air from the transport line from blowing back into the surge bin. The rotary valves were designed with vents that allowed the pressure from the transport line to be relieved before refilling the pocket with switchgrass, but these were not used, and it is not believed that the blowback from the pockets caused any major problems. What we determined to be the biggest problem was the buildup of dust between the ends of the rotating pockets and the stationary valve housing. This created enough friction to trip out the airlock drives on overload. In some airlock designs, an air purge is used to blow out any dust that builds up on the ends. Still other airlocks are designed without an end plate, so this buildup does not occur. Discussions with other airlock manufacturers indicated that the rotary valves might not have been the proper design for our application.

When the rotary airlocks tripped, the feed screws sometimes continued running, filling the area above the airlock with densely packed material. This required the feed system to be shutdown and the airlocks cleared. In addition to numerous motor trips, the housing rotary valves were designed to "rock", so that if something got caught as the pocket came around, the rotary valve isn't damaged. Over the course of testing, both pins that allowed this rocking broke off from the forces exerted on the valves. These pins were welded back on and strengthened, but in the end, the rotary valves had to be held in place with chain pulls because the pins kept breaking off.

\subsubsection{Pneumatic Transport Blowers \& Transport Piping}

The first problem with the pneumatic transport lines was the discovery that some of the flanges on the transport lines had not been adequately tightened. We tightened the bolts and the entire system was rechecked.

A design problem with the transport lines was that no expansion joints had been included for upward contraction of the boiler when the boiler was shutdown. Expansion joints had been 
added for expansion in the north-south and east-west directions, and the transport lines had been hung using constant-tension attachments at the top, but only about $6 \mathrm{in} .(10 \mathrm{~cm})$ had been left between the top of the transport lines and the bottom of the steel I-beams supporting the floor above the transport lines. This wasn't enough clearance for the contraction of the boiler when cooled at shutdown. Fortunately the OGS operating personnel noticed the problem and disconnected the transport lines before shutdown, preventing any serious damage.

The positive displacement blowers presented some problems because the air intakes were undersized. The blowers consisted of an intake air filter, muffler, blower, outlet damper, and check valve at the rotary airlock. Initially the blowers operated fine, but after several weeks of testing, we experienced a few bitterly cold days (which coincided with a blizzard that caused us to miss two days of testing). On these cold days we were not able to get the blowers started, even after changing the pulley ratio on the drives to increase the power to the compressor. Initially we thought the problem might be related to the low oil temperature in the gearboxes, so we added block heaters, changed the oil, and even tried preheating the inlet air during startup. While these methods helped us to start the units, we eventually learned that the air intakes for the compressors were undersized. The original pressure drop calculations indicated that the compressors should each put out 2,900 scfm $\left(1.4 \mathrm{~m}^{3} / \mathrm{s}\right)$ of air at a pressure drop of $4 \mathrm{psi}(28 \mathrm{kPa})$. Our system actually had a pressure drop closer to 2 psi $(14 \mathrm{kPa})$, and even though the blowers were positive displacement, the normal leakage changes the output slightly, so we were actually moving $3,100 \mathrm{scfm}\left(1.5 \mathrm{~m}^{3} / \mathrm{s}\right)$ of air through each pipeline. Our air intakes were designed for $3,000 \mathrm{scfm}\left(1.42 \mathrm{~m}^{3} / \mathrm{s}\right)$, so with the cold and the dust that had collected on the air filters over a couple of weeks of testing, the compressors could not handle the additional startup load. The vendor believed that the air intakes had probably been ordered based on flange size and not based on the airflow, because good design practice would have included a larger safety margin on the airflow. We ordered a larger air intake for one unit and on the other unit, we simply removed the air filter during startup and reinstalled it once the compressor was running. The blower representative also indicated that the installation didn't meet their company specifications, because there was a rigid connection between the compressors and transport line, which could increase the stress on the transport lines due to vibration.

\subsubsection{Control System}

There were numerous issues with the control logic used for the switchgrass system. While the system operated as designed, in many ways it was not practical and did not meet the needs of the operating staff. For example, the control logic allowed for the simultaneous startup of the two $100-\mathrm{hp}(75-\mathrm{kW})$ blowers and the simultaneous startup of the two 300-hp (224-kW) motors on the same circuit. The simultaneous startup of these large motors was not a requirement and did not represent good practice. The control logic also started the feed screws immediately after starting the transport blowers. We preferred to run the transport blowers for 10 minutes before feeding switchgrass to remove any condensation from the transport line that could cause plugging. A bigger concern was a section of control logic that allowed remote startup of the equipment in the switchgrass building by turning a switch in the OGS control room without any advanced warning or alarm in the switchgrass building. 
While it would have been possible to re-write the code for the programmable logic controller (PLC), it was felt that debugging the code would not be a simple task and that it might delay the testing. As a result, much of the equipment was started from the MCC, which limited the ability to use interlocks in the feed-handling system. Manual procedures were implemented to prevent remote startup of the switchgrass equipment.

In future system designs, it is important to get operator input on the control designs. For example, the boiler room operators needed a positive indication that the switchgrass control valves were closed, and while the slide gates at the boiler had proximity switches, which sent a signal back to the PLC, no indicator light was provided for the boiler operating personnel.

\subsection{Summary}

Overall, except for the ongoing issues with the rotary airlocks, all of the problems we experienced were overcome and the system performed well at rates of 12-15 tons/h (11-14 tonne/h). The highest measured rate was 16.8 tons $/ \mathrm{h}$ (15.2 tonne/h) and the Eliminator probably had more capacity, if needed. (The Eliminator was delivered with two 300-hp (224-kW) motors, which rarely required more than $100 \mathrm{hp}(75 \mathrm{~kW})$ when operating.)

The ability to make on-site equipment modifications and repairs was extremely important to the success of our testing at OGS. Any of the above problems could have resulted in a week or more of downtime without the experienced maintenance personnel on-site and their suppliers that airfreighted parts overnight from Chicago, preventing potentially lengthy delays.

\subsection{LABOR/OPERATING PERSONNEL}

The system used for this testing was very labor intensive, although it was designed as such to minimize capital costs for this short-term testing. When running at 15 tons $/ \mathrm{h}(13.6 \mathrm{tonne} / \mathrm{h}), 30$ $1,000 \mathrm{lb}(454 \mathrm{~kg}) 3 \times 4$ bales must be handled every hour, or one every two minutes. Using $3 \times 3$ bales required 43 bales to be handled per hour. That made driving the fork truck a full-time job, because little more than 2 tons (1.8 tonnes) of switchgrass could be placed on the debaler inlet conveyor at any given time.

The bale handling was time consuming, but so was twine removal, which was done manually by a second person. Each $3 \times 3$ bale had 3 strings. Each $3 \times 4$ bale had 5 strings, meaning a person might be required to cut and pull out about 150 pieces of twine per hour, or one string every 24 seconds! Ergonomically, this was a job that could not be done for extended periods of time because it involved bending, pulling, and walking around on uneven footing. Like driving the fork truck, twine removal was a full-time job.

Another laborer was required to monitor the feed handling system, and at high feed rates, this person was responsible for monitoring the inlet chute to the Eliminator. If the chute plugged, the operator would temporarily stop the flow of material from the debaler and wait to see if the plug cleared itself. If it did not, the operator would stop the flow, manually clear the inlet chute, then go back and restart the debaler flow. Depending on the feed rate and the quality of the bales, the inlet chute might go hours without plugging, or only minutes. 
The above three jobs required full-time attention. In order to provide breaks, an extra person was required for relief. That meant a minimum operating crew of four people was needed to man the switchgrass building during the first round of testing. This isn't practical in a commercial system, considering the entire 725-MW OGS power plant can be run with fewer people than this. The second co-fire test campaign will concentrate on the testing of an automated system for feed handing. In Europe, unattended operation has been demonstrated and even OGS has most of their coal-handling system designed with monitors that allow it to be safely operated from the control room under normal conditions. While there may be people monitoring the operation of the feed handling system during the second round of co-fire testing, the system should be designed to operate with minimal operator attention.

\subsection{FIRE PROTECTION}

There was one minor incident during the first co-fire test campaign, but there was no damage to equipment and no one was injured. At approximately 2:00 a.m. the morning of January 16, OGS plant personnel noticed smoke coming from the bottom of the baghouse, found a small fire smoldering inside, and quickly extinguished it with water. The fire did not damage any of the bags.

Although the baghouse was emptied every night before being shutdown, upon further investigation, it was discovered that some of the twine that had made it through the debaler had wrapped around the bag supports in the bottom (dirty-side) of the baghouse. Dust passing through the baghouse had built-up on these supports and at some point been ignited by a spark, presumably from the Eliminator.

After this incident, the operating personnel periodically inspected the dirty side of the baghouse and removed any debris that had collected. This incident illustrated another issue regarding switchgrass testing: the need for a written emergency response plan. Because of the design of our system and the requirement of negative pressure for dust control, the baghouse in our system would allow any fire to quickly spread through the entire system if the first response of the operating personnel is anything other than shutting off the baghouse blower. For future testing, it would be advisable to connect the fire pull alarms and flame detectors to a circuit to shutoff the baghouse blower in case of a fire.

For the first co-fire test campaign, there was no sprinkler system in the bale storage area of the building, although some limited firefighting equipment was installed. In the event of a fire in the bale storage area, some method of quenching the fire will need to be devised and there will likely be compartmentalized storage and firewalls included in the final design, to prevent fire from spreading to the equipment areas. 


\subsection{BOILER PERFORMANCE}

When we started testing, we checked to make sure that the boiler responded normally to the additional transport air entering through the switchgrass system, and that the boiler fuel flow was not adversely affected by the additional switchgrass fuel. As expected, the minor airflow from the transport system and the addition of the low flows of switchgrass were undetectable in the boiler control room. If it weren't for the ability to observe the switchgrass leaving the nozzle and entering the boiler, there was no way of knowing we were burning any switchgrass at all.

In the case of the Southern Company's switchgrass testing in Gadsden, Alabama, they found that the cold transport air had a significant effect on boiler efficiency. At OGS, the transport air from the switchgrass system amounted to $6,200 \mathrm{scfm}\left(2.9 \mathrm{~m}^{3} / \mathrm{s}\right)$ of air compared to the 1.1 million $\operatorname{scfm}\left(519 \mathrm{~m}^{3} / \mathrm{s}\right)$ of air normally used for combustion. The operation of our transport blowers had no noticeable effect on the boiler.

As for the fuel flow into the OGS boiler, it must be understood that at our target co-firing rate at $12.5 \mathrm{ton} / \mathrm{h}(11.3$ tonne $/ \mathrm{h})$, the switchgrass represented only about $2.5 \%$ heat input to the boiler. The commercial system would be 25 ton/h (22.7 tonne/h) or $5 \%$ heat input. In December, our typical firing rate was $4-6$ tons $/ \mathrm{h}$ (3.6-5.4 tonne $/ \mathrm{h}$ ), or about $1 \%$ heat input from switchgrass. In the OGS boiler, soot blowing could cause more than a $2 \%$ change in fuel flow, so it was difficult to link any changes in boiler performance with the low co-firing rates in December. In January, on the other hand, it was possible to see changes of up to $3 \%$ in coal flow in response to changes at the higher switchgrass flows. However, changes in operation by the boiler control room staff could still hide these effects. As the boiler operators became comfortable with the switchgrass operations - meaning the operators could detect little, if any, effect on their boiler - the operators would allow the switchgrass team to ramp up and ramp down the switchgrass flow as desired.

Toward the end of testing in January, the boiler was losing capacity due to fouling in the reheater and superheater sections of the boiler. While this did not appear to affect the heat transfer in the boiler, it did cause an increased pressure drop through the boiler tubes, increasing the loads on the induced draft fans. This was a normal occurrence just before shutdown, exacerbated by the fact that one bank of soot blowers on the non-co-fire side of the boiler had been out of service. Unfortunately, no data was available for comparing the fouling while co-firing with the normal fouling rate observed in the boiler. During the shutdown immediately after the co-fire testing, inspections indicated no unusual fouling, slagging, or deposits that could be linked to the switchgrass co-fire testing.

One observable effect of the co-firing was the collection of unburned nodes in the bottom ash pond. The nodes from the joints in the switchgrass stems were not reduced in size by the Eliminator. Due to their size and density, they would quickly drop to the bottom of the boiler with little or no charring, even though they would pass through two lower rows of coal burners. The nodes were easily detected at the ash pond because they would float to the surface, then collect around the edges of the ash pond. While they don't degrade the quality of the ash, which was generally used for fill, cover, or landscaping, the nodes did represent unburned fuel. 


\subsection{RECOMMENDATIONS}

1). For the next round of co-fire testing, a firm with more experience with feed handling systems, possibly someone with agricultural processing experience in addition to power plant knowledge, would be advantageous. Not only should the firm have experience handling lowdensity materials that are prone to bridging, but the firm should also have operational experience. Practical design and flexibility in the equipment controls is important to the operation of the switchgrass equipment.

2). All switchgrass-handling equipment should be covered and kept under a slight negative pressure. This prevents any dust from escaping into the room, minimizes labor for housekeeping, avoids high-volume dust collection equipment, and minimizes the potential fire hazard.

3). Pulling a suction on grinding equipment or providing some other means of assisted transport though the grinder is important. Pulling a suction on the Eliminator more than tripled its throughput. One of the hammer mill manufacturers that visited the site agreed and said that pulling a suction on a hammer mill will normally double its capacity.

4). Monitoring equipment should be installed on pneumatic transport lines to sense switchgrass flow. It would be helpful to the plant operating personnel to know exactly when switchgrass is going to the boiler. During our testing, the boiler room personnel had an indicator for when the equipment was running, but if we had a plug, we could go an hour or more without sending fuel to the boiler. Having some method of monitoring the switchgrass flow would also help with data analysis. Tech-wise has a simple optical method for obtaining qualitative results that they have used for testing in Denmark.

5). A detailed test plan is needed for stack testing. Because this information is some of the only certified data submitted to the Iowa DNR, it must be conducted under carefully controlled conditions. Procedures should be in place to prepare for the testing and enough time should be allotted for conducting the testing, with soot blowing between tests if needed.

6). Additional time needs to be included for equipment shakedown. Each piece of equipment should be tested for normal operation then checked to see if it is operating at its design capacity. Several of the early problems due to incorrectly installed equipment could have been identified and avoided with a more thorough pre-startup inspection.

7). The design should ensure that all downstream equipment has the capacity to handle the peak flow of the equipment feeding it. This might require limiting the flow of the upstream equipment. Interlocks should also be included to shutoff upstream equipment when a piece of downstream equipment fails.

8). The data collection requirements and analysis methods should be determined before the start of testing and a sample set of data should be collected and checked before the testing begins. This minimizes the amount of excess data collected, reducing the time for data analysis. It also assures that the data being collected is of a high quality and that nothing is missing. A daily 
check of the data is important, so if there are any process anomalies, someone can check with the operators and see if there was a known cause, before this information is forgotten.

9). Arrangements should be made for on-site moisture determinations. Samples collected and sent to NREL by overnight mail gave moistures of about $11 \%$, while moisture measurements at Hazen Research of material that had been stored for several months averaged about $6 \%$. The onsite moisture probe was only able to read bale moistures down to $14.5 \%$. This moisture data is critical for determining the heat input to the boiler.

10). More robust record-keeping is required for documenting startup times, shutdown times, feed rates, and operating problems. This not only requires an efficient and simple record keeping system, but also requires diligence on the part of the test supervisors to check that all the required information is being recorded. The best way to accomplish this is to have one technician whose sole responsibility is to record operational data during testing.

11). The support of management at the host facility is extremely important in coordinating and providing power plant personnel during testing. It is also important to set aside time to keep the operators informed about the project. All of the operators were very interested in the project and often had good ideas on how to improve the testing coordination and equipment operation. 


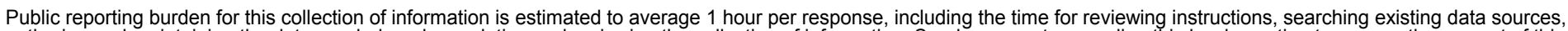

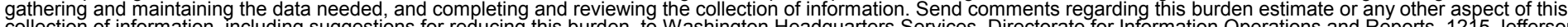

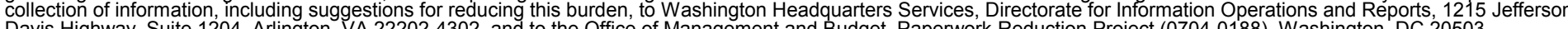

Davis Highway, Suite 1204, Arlington, VA 22202-4302, and to the Office of Management and Budget, Paperwork Reduction Project (0704-0188), Washington, DC 20503.
1. AGENCY USE ONLY (Leave blank)
2. REPORT DATE
3. REPORT TYPE AND DATES COVERED
July 2002
Milestone Report

4. TITLE AND SUBTITLE

Summary of Chariton Valley Switchgrass Co-Fire Testing at the Ottumwa Generating

Station in Chillicothe, lowa

5. FUNDING NUMBERS

BP01.1026

6. $\operatorname{AUTHOR}(\mathrm{S})$

Wade A. Amos

7. PERFORMING ORGANIZATION NAME(S) AND ADDRESS(ES)

8. PERFORMING ORGANIZATION REPORT NUMBER

9. SPONSORING/MONITORING AGENCY NAME(S) AND ADDRESS(ES)

National Renewable Energy Laboratory

1617 Cole Blvd.

Golden, CO 80401-3393

10. SPONSORING/MONITORING AGENCY REPORT NUMBER

NREL/TP-510-32424

11. SUPPLEMENTARY NOTES

12a. DISTRIBUTION/AVAILABILITY STATEMENT

National Technical Information Service

12b. DISTRIBUTION CODE

U.S. Department of Commerce

5285 Port Royal Road

Springfield, VA 22161

13. ABSTRACT (Maximum 200 words)

Results of the switchgrass co-firing tests conducted at the Ottumwa Generating Station in Chillicothe, lowa as part of the Chariton Valley Biomass Project.

14. SUBJECT TERMS

15. NUMBER OF PAGES

biomass power, co-firing, switchgrass

16. PRICE CODE

17. SECURITY CLASSIFICATION

OF REPORT

Unclassified
18. SECURITY CLASSIFICATION OF THIS PAGE Unclassified
19. SECURITY CLASSIFICATION OF ABSTRACT

Unclassified
20. LIMITATION OF ABSTRACT

UL 